\title{
O COTIDIANO DE UMA CRECHE: compartilhando experiências
}

Creche Nossa Senhora Aparecida - Prefeitura Municipal de Florianópolis

Adriana de Souza Broering adrianabroering@gmail.com

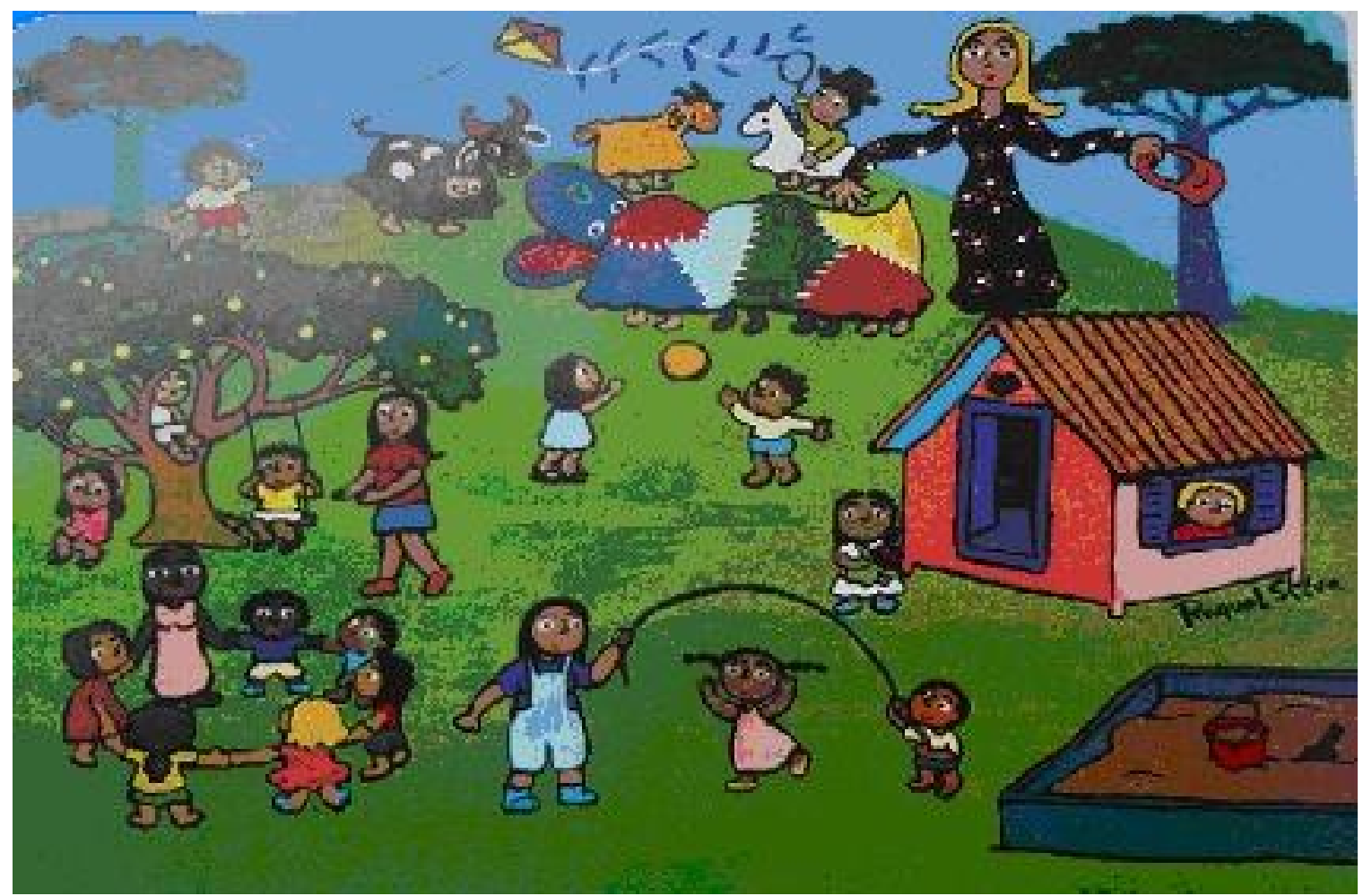

Pintura realizada pela artista Raquel Silva para a capa da agenda da Creche

"Recolher uma experiência escolar e torná-la pública não é tarefa fácil, sobretudo se pretendemos manter a idéia de que o que aqui se apresenta tem um caráter singular, e, portanto, não reproduzivel. Há de ser o leitor, se encontrar alguma utilidade ou inspiração nestes exemplos, quem irá fazer seu próprio caminho e sua adaptação".

Fernando Hernández, 1998 
Assumindo a dificuldade de falar da experiência e sem pretender afirmar um modelo, este artigo apresenta a experiência vivida e compartilhada por profissionais, crianças e famílias da Creche Municipal Nossa Senhora Aparecida, conhecida como Creche Pantanal.

Desde abril de 1987, ano de sua fundação, a Creche Municipal Nossa Senhora Aparecida compõe-se por um coletivo que vive diferentes tempos da vida; são crianças e adultos compartilhando sonhos, emoções, medos, desejos, com diferentes ritmos, necessidades e expressões, descobrindo e desenvolvendo múltiplas linguagens, para dizer dessa aprendizagem mútua de convívio, conhecimento e afeto. No desenho desse cotidiano, diferentes projetos marcam a intencionalidade das ações, tanto nos grupos de crianças, quanto no coletivo da creche. Nesse espaço, crianças, profissionais, mães e pais que viveram (e vivem) a instituição, são protagonistas de uma história que vem sendo composta, criada e recriada cotidianamente, há 21 anos.

\section{O início do ano}

Como em toda instituição de educação infantil, o início de cada ano demarca um recomeço. No mês de fevereiro é tempo de acolher, de planejar, de traçar objetivos, para continuar caminhando. Com um quadro funcional bastante rotativo, uma vez que as instituições recebem sempre um significativo número de profissionais substitutos, torna-se necessário retomar o caminho percorrido, com os profissionais que chegam. Tanto os que já faziam parte da creche, quanto os "novos", têm desejos, idéias, crenças, medos, valores, sonhos, certezas, experiências, conhecimentos, objetivos, dúvidas, sentimentos, expectativas. O que fazer com tudo isso? É o permanente desafio da construção de um trabalho em grupo! O trabalho inicia-se, então, com essa peculiaridade, uma "luta" em viver as diferenças, "sem perder a ternura jamais!".

Começamos refletindo sobre princípios e concepções. Um momento para ler e refinar a organização administrativa e pedagógica já estruturada e rever o Projeto Político Pedagógico (PPP). É preciso refletir, também, sobre nossa humanidade, pensar sobre o que nos une como humanos que somos. E pensar, essencialmente, sobre o que nos une como profissionais que trabalham em uma Creche da Rede Pública Municipal, especialmente, a educação das CRIANÇAS! Assim, com esse consenso, toda a organização dentro da instituição segue, caminha, no sentido de assegurar e garantir esse direito fundamental. Outro acordo firmado, forte marca desse grupo, é o "combinado" de que tudo o que for definido no grupo, deve ser abraçado com responsabilidade compartilhada por todos.

Lidar com tudo isso não é tarefa fácil, pois sempre aparecem incertezas, dificuldades, desentendimentos, problemas. Mas não estamos sós, somos um grupo, e a busca por fazer o melhor no trabalho, junto às crianças, nos acompanha e, acima de tudo, tem nos motivado.

Para nós, o envolvimento de todos os integrantes e segmentos é fundamental para a constituição e consistência do grupo. Acreditamos e praticamos o princípio de que "ninguém é tão 
grande que não possa aprender, nem tão pequeno que não possa ensinar". Mas, como aponta Katz (1999, p. 46):

(...) os indivíduos não podem apenas se relacionar uns com os outros: eles precisam relacionar-se uns com os outros acerca de algo. Em outras palavras, os relacionamentos precisam conter interesse ou envolvimento mútuo, cujos pretextos e textos proporcionem a interação adulto-criança.

Com essa concepção, que busca envolver educadores de todos os segmentos, a Creche organiza seu trabalho em torno de projetos que chamamos de projetos coletivos, planejados para envolver, crianças/crianças, crianças/adultos, adultos/adultos, crianças/adultos/ambientes.

\section{Uma visão dos projetos coletivos}

A história dos projetos coletivos também é construída no processo e ano após ano, os quais têm crescido em qualidade e quantidade. Até 2002 tinha-se três projetos, dentre os quais: refeitório, boi-de-mamão, confraternizações; hoje são treze projetos: refeitório, acolhida/despedida, boi-demamão, confraternizações, culinária, teatro, educação ambiental, educação estética dos educadores, organização dos espaços para atividades coletivas, saídas e passeios, parque, hora do descanso.

A história pode ser descrita mais ou menos assim: os projetos são criados a partir de uma necessidade ou desejo, passam por um período de estruturação, quando necessário procuramos fundamentação teórica. Depois de implantados são constantemente reavaliados, replanejados e quase sempre ampliados. Nesse processo, temos o que poderíamos chamar de filosofia. Pensamos que se o projeto foi proposto é porque tinha um objetivo a cumprir, seria importante para as crianças e/ou adultos. Por isso, não desistimos nas primeiras dificuldades. $\mathrm{O}(\mathrm{s})$ objetivo(s) que fez com que o projeto "nascesse", é relembrado/resgatado, e após observações e diagnósticos, as causas/motivos das dificuldades são atacadas para que ele possa "desenvolver-se".

No início todos os projetos funcionavam a partir das comissões, divididas em blocos, sendo Bloco A para os projetos que priorizavam as interações, bloco B, para as atividades culturais e bloco C, para as confraternizações. Para alternância de papéis e participação em todos os blocos, a regra era cada educador fazer parte de pelo menos uma comissão de cada bloco. Pensando no aprimoramento do processo, no ano de 2008 criamos o que temos chamado de "grupos de ação", os quais são organizados para pensar e encaminhar os projetos, sendo cinco os grupos de ação.

Como definir, entre todas as ações desenvolvidas no trabalho junto às crianças, quais as mais significativas no momento? Para tanto, fez-se necessário definir alguns critérios e, então, escolher quais projetos seriam coordenados pelos grupos de ação. Escolhemos o teatro, por avaliarmos que havia carência do exercício e do oferecimento dessa linguagem na Instituição; demos prioridade à educação ambiental, como ação imprescindível, uma vez que enquanto cidadãos devemos ser 
responsáveis pelos recursos naturais que utilizamos. Pensamos também em dar ênfase aos projetos refeitório-parque, acolhida-despedida e hora do descanso, que já estão incorporados à prática cotidiana e representam potencialidades do trabalho, mas necessitam ampliar a reflexão sobre as ações desenvolvidas. No caso do projeto educação estética nós o escolhemos por acreditar ser necessária, também, uma formação artístico/cultural para os educadores. Acreditamos ser fundamental investir numa educação para o sensível, através de experiências que promovam a fruição e o estranhamento diante da arte, diante do novo e das diferentes linguagens.

A constituição dos "grupos de ação" aconteceu por adesão, cada educador definiu no início do ano o grupo do qual gostaria de participar. Após a formação, cada grupo escolheu um coordenador. Para a operacionalização dos grupos, temos realizado encontros, nos quais os integrantes planejam ações e/ou atividades/momentos procurando motivar, envolver e/ou formar toda a comunidade educativa.

Mas nem só de "grupo de ação" vivem os projetos coletivos da creche do Pantanal; ainda continuamos com a formação de comissões, agora mensais, para a organização dos espaços para atividades coletivas e confraternizações. Essas comissões são definidas no início do ano. Assim como nos "grupos de ação", nas comissões os participantes planejam e articulam para que o momento aconteça, mas a execução é garantida por todos os profissionais da instituição, inclusive os que planejaram a ação. Em função da avaliação e replanejamento do trabalho alguns projetos específicos hoje não têm comissões, são coordenados, especialmente, pelos responsáveis pelas atividades. Os projetos saída-passeios e boi-de-mamão, por exemplo, são coordenados pela professora de Educação Física. O projeto culinária é coordenado pela cozinheira readaptada e o projeto parque pela Direção.

Nas confraternizações da Páscoa, Homenagem às mães, Festa junina, Homenagem aos pais, Mês de outubro, Despedida do Grupo 5 e Natal, temos sempre uma comissão de apoio formada pela Direção, Supervisão e a professora de Educação Física. Esta comissão apoiadora tem, ainda, um importante objetivo, procurar garantir os princípios e concepções definidos no PPP, uma vez que para além das datas comemorativas, as confraternizações têm, na vida da Creche, assumido, a cada ano, um papel educativo crítico em relação às pressões do consumo, transgredindo o instituído socialmente e qualificando o momento. O desejo é fugir da pressão de consumo que o comércio impõe nestes períodos aos adultos e, principalmente, às crianças.

No caso da Páscoa, que citarei como exemplo, a imagem do coelho está a "serviço" da ampliação de repertórios; a decoração do espaço é realizada, essencialmente, com verduras e frutas da "horta" do coelho. No cardápio potencializa-se o preparo de alimentos com verduras e leguminosas. De início, uma coelhinha - adulto fantasiado - recebe as crianças com cenourinhas, daquelas bem pequeninas, que todos experimentam curiosos. Durante a semana um coelhinho - de verdade! - vem "morar" na creche, há também momentos com teatros e outras atividades artísticas e culturais.

Durante estas datas comemorativas não paramos os projetos de trabalho desenvolvidos nos grupos para dar ênfase à comemoração. Cada vez mais a idéia tem sido a de utilizar os projetos 
coletivos, para a preparação e/ou encaminhamentos desses momentos. Na Páscoa deste ano, por exemplo, foram utilizados os projetos da culinária, do refeitório, da acolhida e do teatro para se pensar e viver este momento.
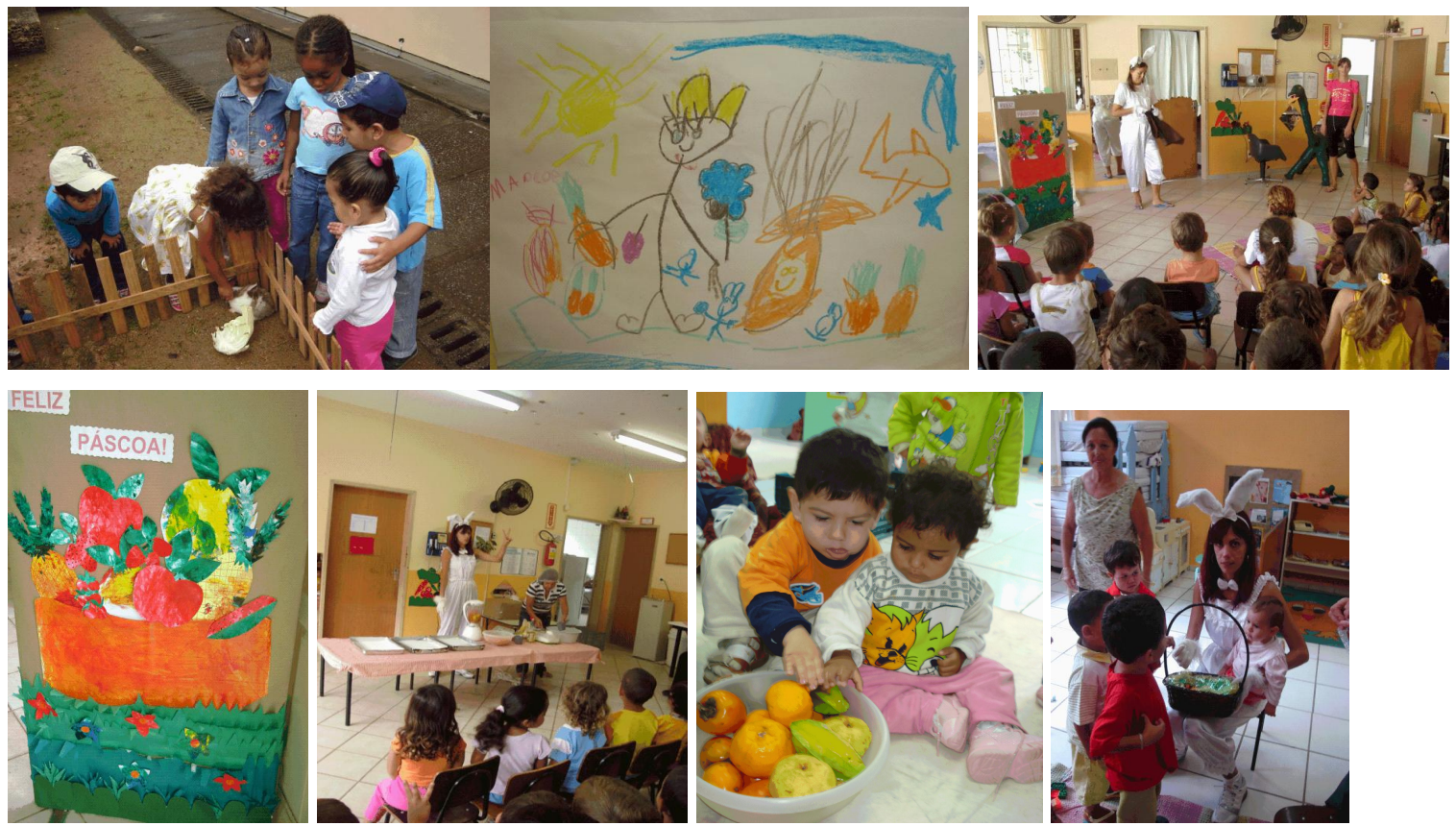

Os projetos coletivos têm a participação de todos, conforme relatamos acima, existe uma especificidade no trabalho da coordenação pedagógica e da supervisora, a qual consiste em assessorar e incentivar as ações, acompanhando todo o processo.

Atualmente, os projetos coletivos são realizados numa periodicidade pré-estabelecida no PPP.

Acolhida e saída: acontecem todos os dias das 7:00h às 8:00h e das 17:40h às 19:00h.

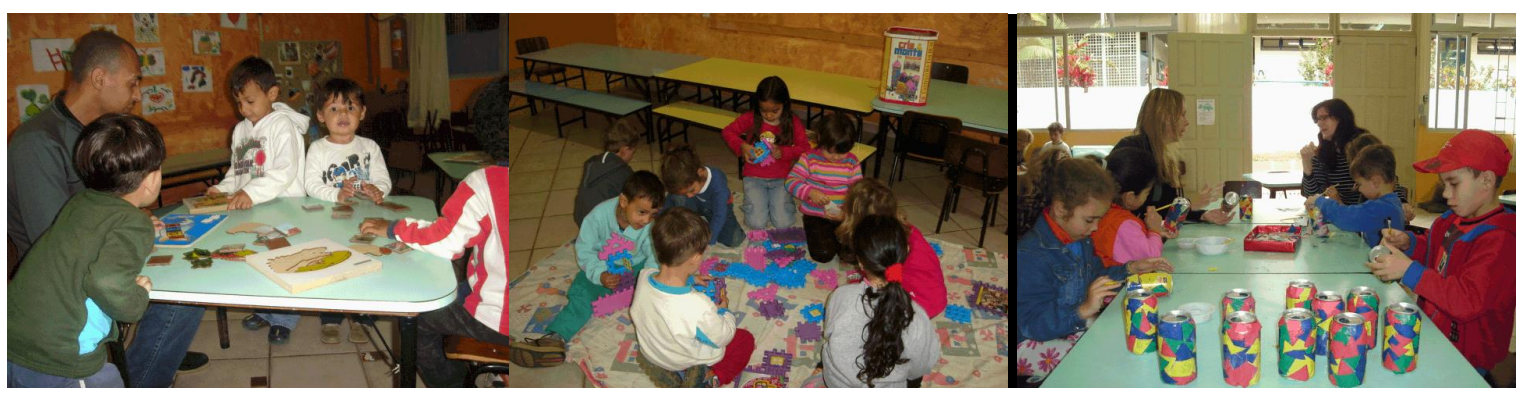

Boi-de-mamão dança a cada quinze dias, com alternância de horários.

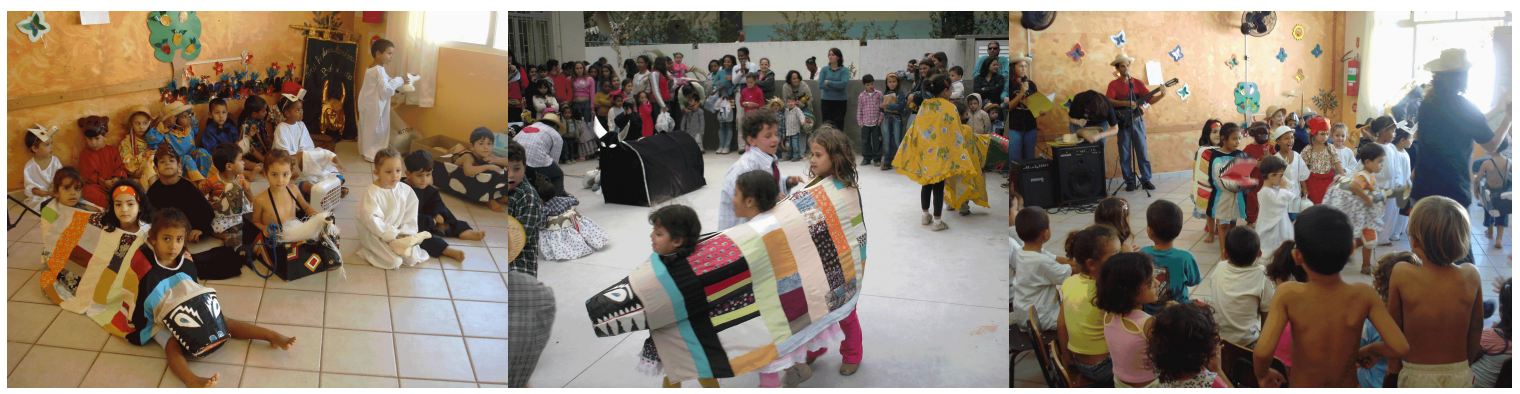


Culinária: acontece numa semana com os grupos 1,2,4 e em outra semana com os grupos 3 e 5, em períodos alternados (manhã, tarde). É importante dizer que nesse projeto priorizamos os alimentos que possam ser assados ou cozidos, após o manuseio.
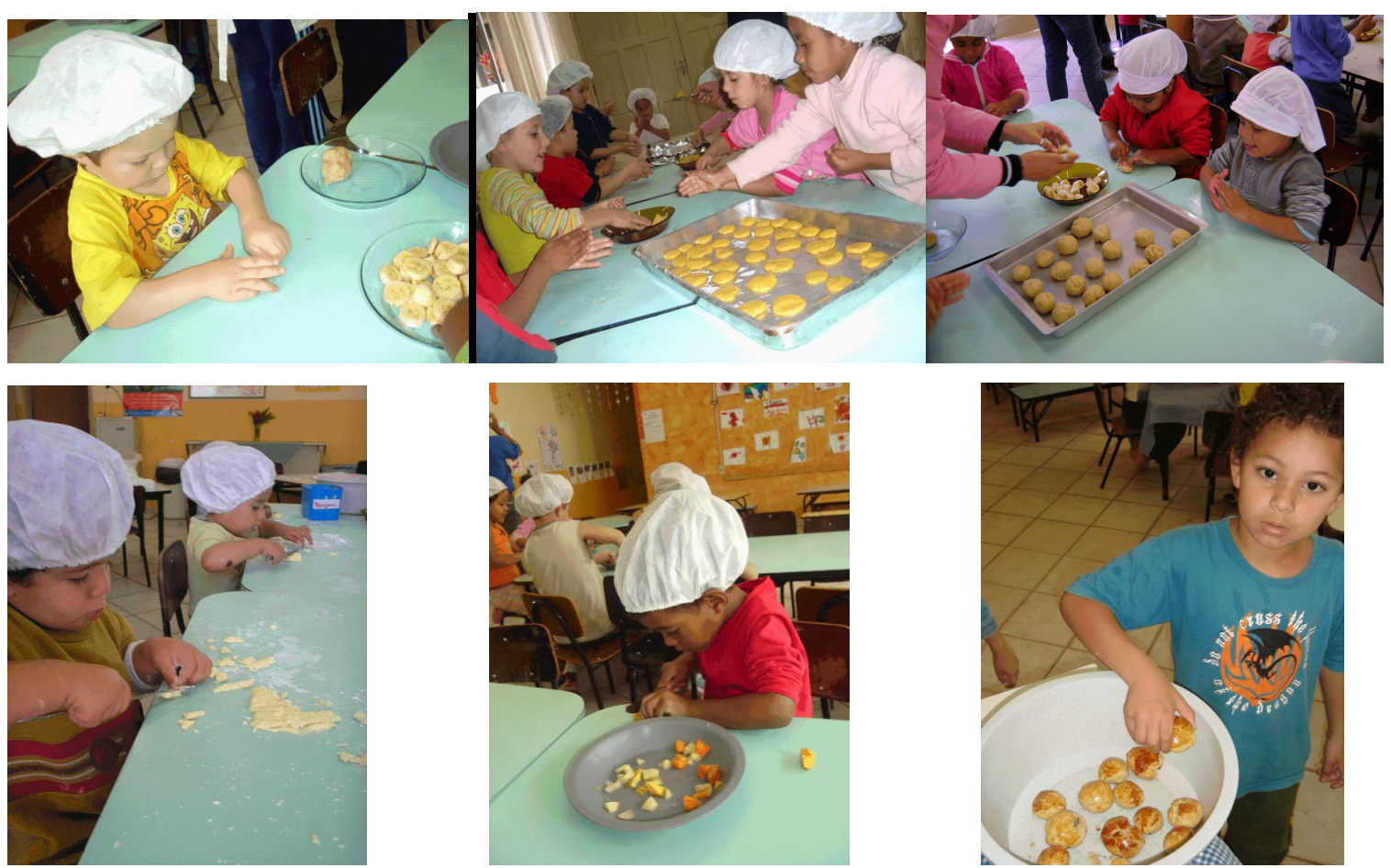

Organização de espaços para atividades coletivas: acontece no parque, todas as segundasfeiras e em todo o espaço da creche, na última sexta-feira de cada mês.

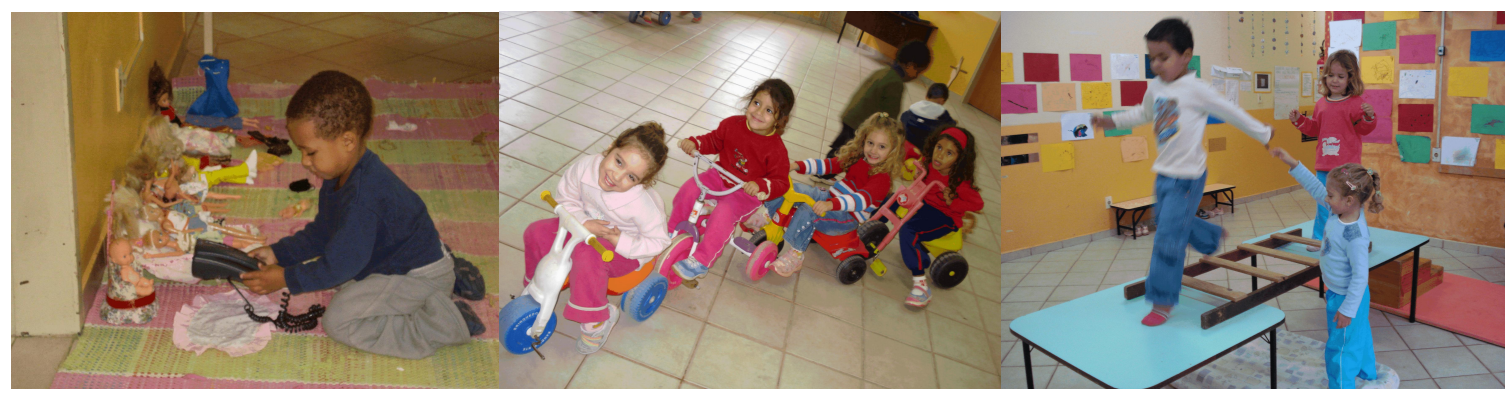

Parque: A ida das crianças ao Parque, devido ao tamanho reduzido do mesmo, tem horários planejados, sendo diferenciados nas segundas e sextas.. Apesar de pequeno, temos um espaço privilegiado: as árvores que plantamos há 19 anos, hoje permitem a luz no inverno; nos dão sombra no verão; muito trabalho no outono; mas um tapete de flores na primavera. Assim, enquanto brincam no parque, crescem as crianças e as árvores. 

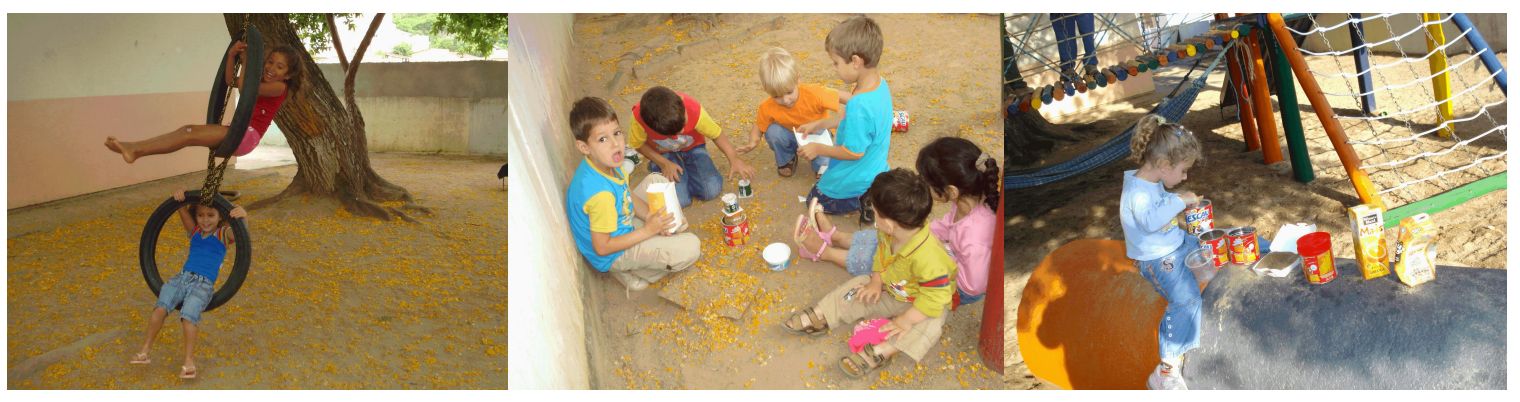

Teatro: não tem um cronograma definido, embora este ano o grupo de ação tenha previsto atividades quinzenais.
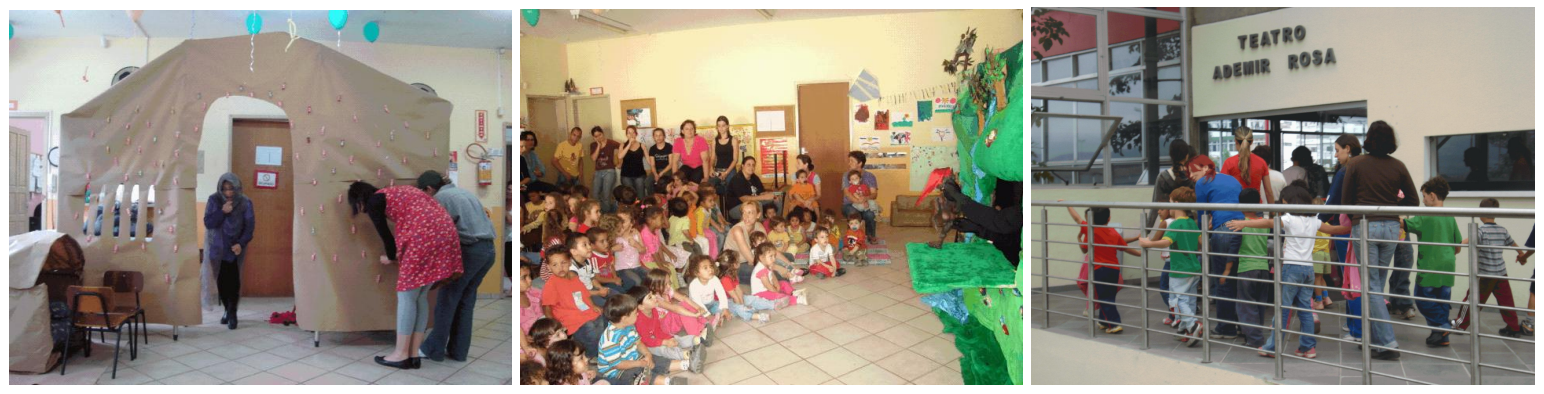

Educação Ambiental: acontece por meio da separação do lixo orgânico e dos recicláveis, bem como da coleta seletiva realizada toda quarta-feira. Realizam-se também ações educativas diárias para a conscientização de questões ambientais mais urgentes, como o desperdício de água potável e a necessidade da redução do lixo. Realizamos também brechós com a participação das famílias e da comunidade.
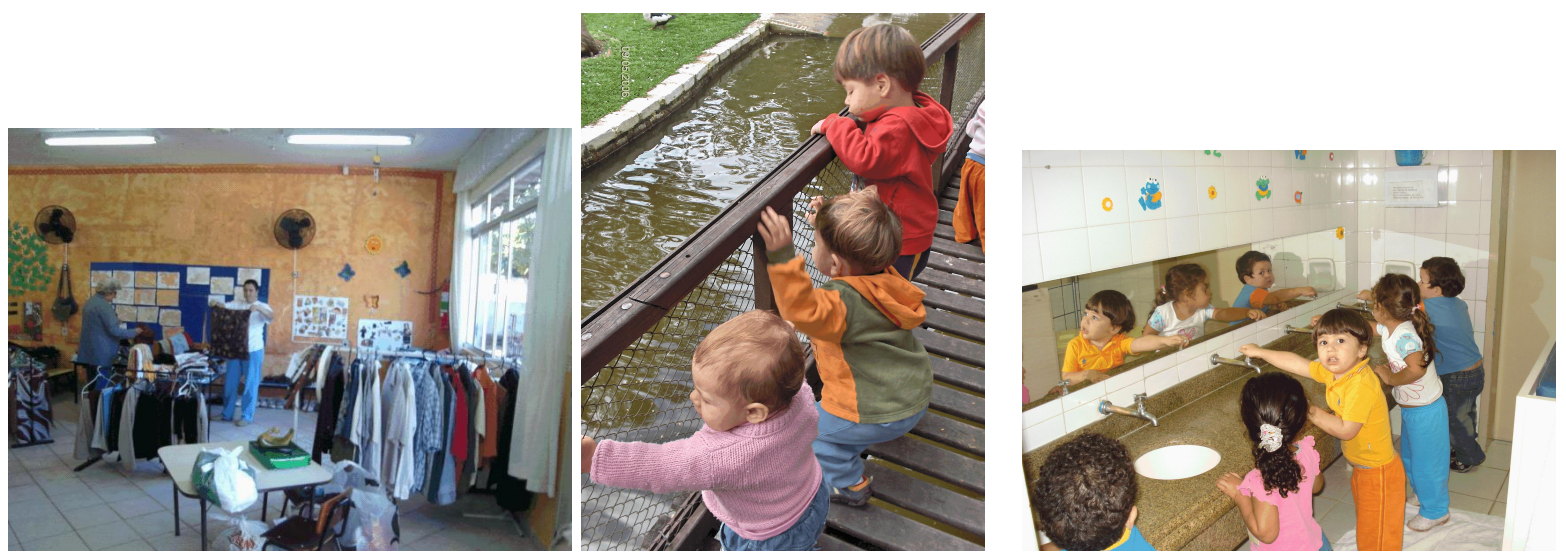

Hora do descanso: organizamos diariamente seis espaços, três para receber as crianças que desejam dormir e outros três espaços para acolher as que não querem dormir. 


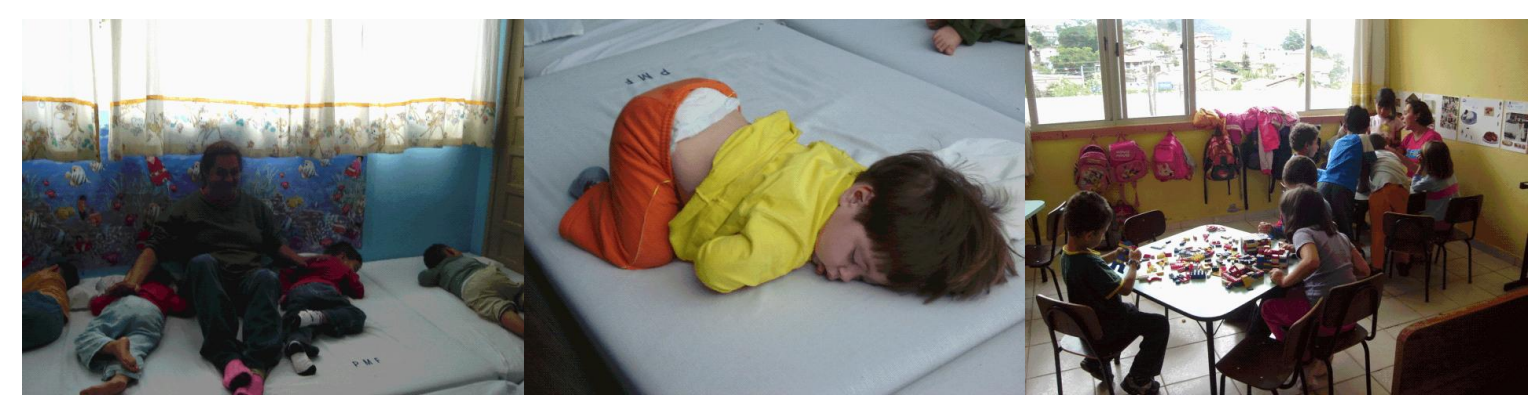

Refeitório: temos o sistema de buffet para as crianças maiores de três anos, onde diariamente "usamos roupa de domingo", isto é, há toalhas e ornamentos nas mesas.
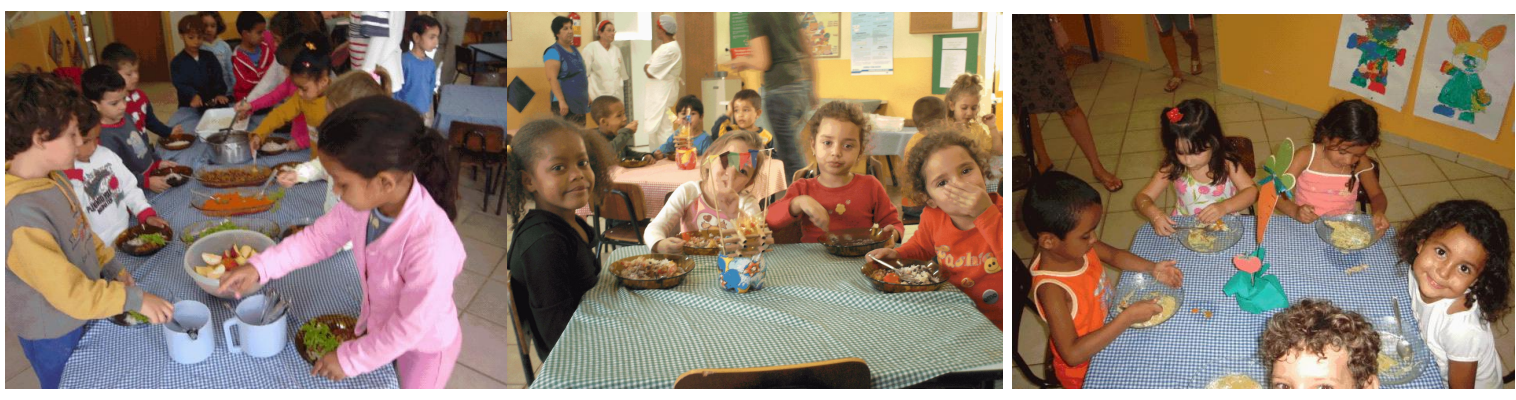

Saídas e Passeios: são realizados em média uma vez por mês, o que equivale a oito saídas ou passeios por ano.

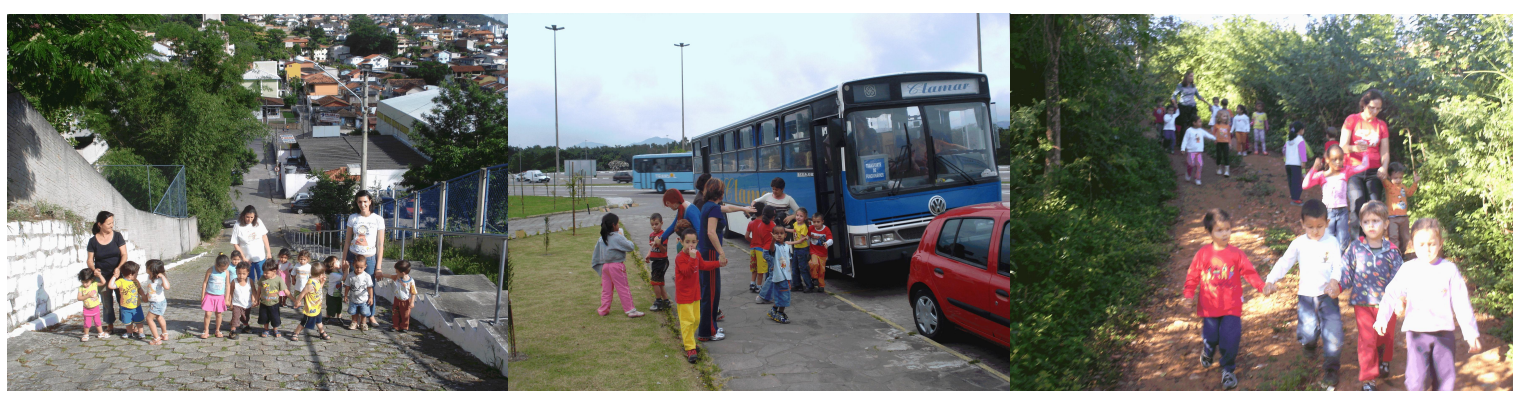

\section{Espaços e organização dos grupos de crianças}

Nas salas de referências temos agrupamentos mistos. A idéia de grupos com crianças de idades diferenciadas trata-se, também, de uma concepção definida ao longo dos anos com o coletivo.

Acreditamos na interação como importante forma das crianças aprenderem. Mas não basta, os agrupamentos serem verticais, o espaço também tem que estar planejado para que as interações sejam potencializadas. Por isso, as salas de convívio dos grupos são organizadas em zonas circunscritas, ou como são comumente denominadas: cantos. Estes espaços pretendem facilitar e manter as interações entre as crianças. Como aponta Zabalza (1998,p.121 ),

Esta facilitação ocorre em função da diminuição da probabilidade de interrupção da atividade por outras crianças ou pela educadora, o que é freqüente em arranjos 
abertos. Ademais, as zonas circunscritas, favorecendo proteção ou privacidade, favorece à criança focalizar sua atenção tanto na atividade que está sendo desenvolvida bem como ao comportamento do parceiro, requisitos essenciais para ocorrência de interação entre coetâneos.

O espaço é uma importante ferramenta pedagógica, e Faria (1999, p.85 ) afirma também que:

[...] o espaço e o modo como é organizado resulta sempre das idéias, das opções, dos saberes das pessoas que nele habitam. Portanto, o espaço de um serviço voltado para crianças traduz a cultura da infância, a imagem da criança, dos adultos que o organizam, é uma poderosa mensagem do projeto educativo concebido para aquele grupo de crianças.

E por isso o espaço necessita ser planejado. Como afirma Loris Malaguzzi, apud GANDINI, 1999, p. 157:

[...] Valorizamos o espaço devido a seu poder de organizar, de promover relacionamentos agradáveis entre pessoas de diferentes idades, de criar um ambiente atraente, de oferecer mudanças, promover escolhas, e a seu potencial para iniciar toda a espécie de aprendizagem social, afetiva, cognitiva. Tudo isto contribui para uma sensação de bem estar e segurança nas crianças...

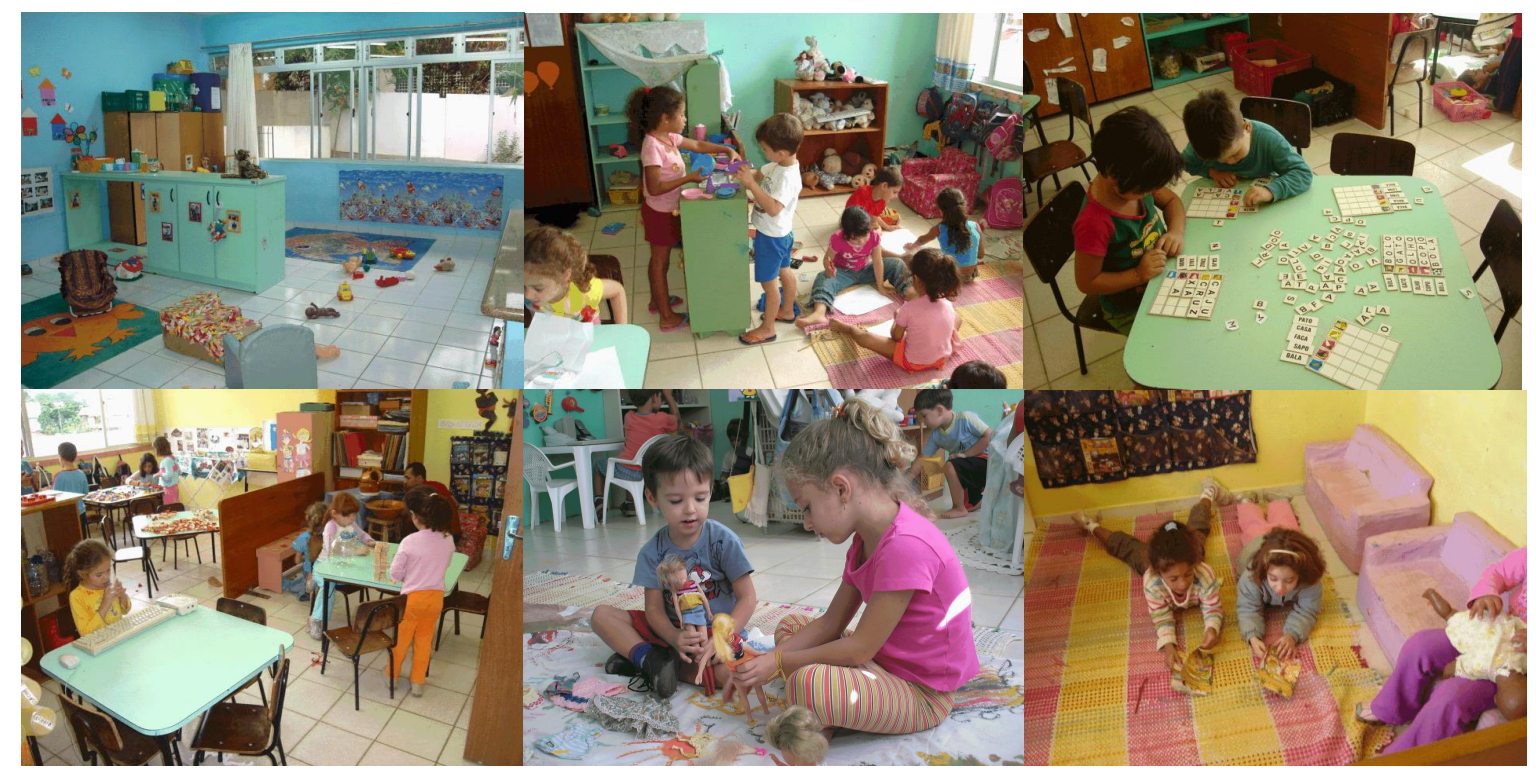

No cotidiano dos grupos, os profissionais responsáveis desenvolvem seus trabalhos, procurando seguir a proposta de "projetos de trabalho". Cada grupo tem, também, um cronograma 
diário para oportunizar às nossas crianças o acesso a diferentes linguagens. Diante da necessidade de oportunizar às crianças uma ampla diversificação de vivências e expressões, esse quadro deseja organizar o cotidiano de forma a privilegiar uma série de linguagens, para além do trabalho com projetos. Nessa forma de organizar o trabalho seguimos a indicação de KATZ (1999, p. 45) quando relata que, no norte da Itália,

[...] As crianças engajam-se em muitas outras atividades, além do trabalho em projetos. A oportunidade para uma ampla gama de jogos espontâneos com blocos, dramatização, brincadeiras ao ar livre, audição de histórias, encenação de papéis, culinária, tarefas domésticas e atividades ligadas a arrumação pessoal, bem como atividades como pintura, colagem, e trabalhos com argila, estão disponíveis a todas as crianças diariamente.

Da mesma forma, também em nossa creche, temos a preocupação com a freqüência de oportunidades com vistas à ampliação e diversificação das vivências das crianças.
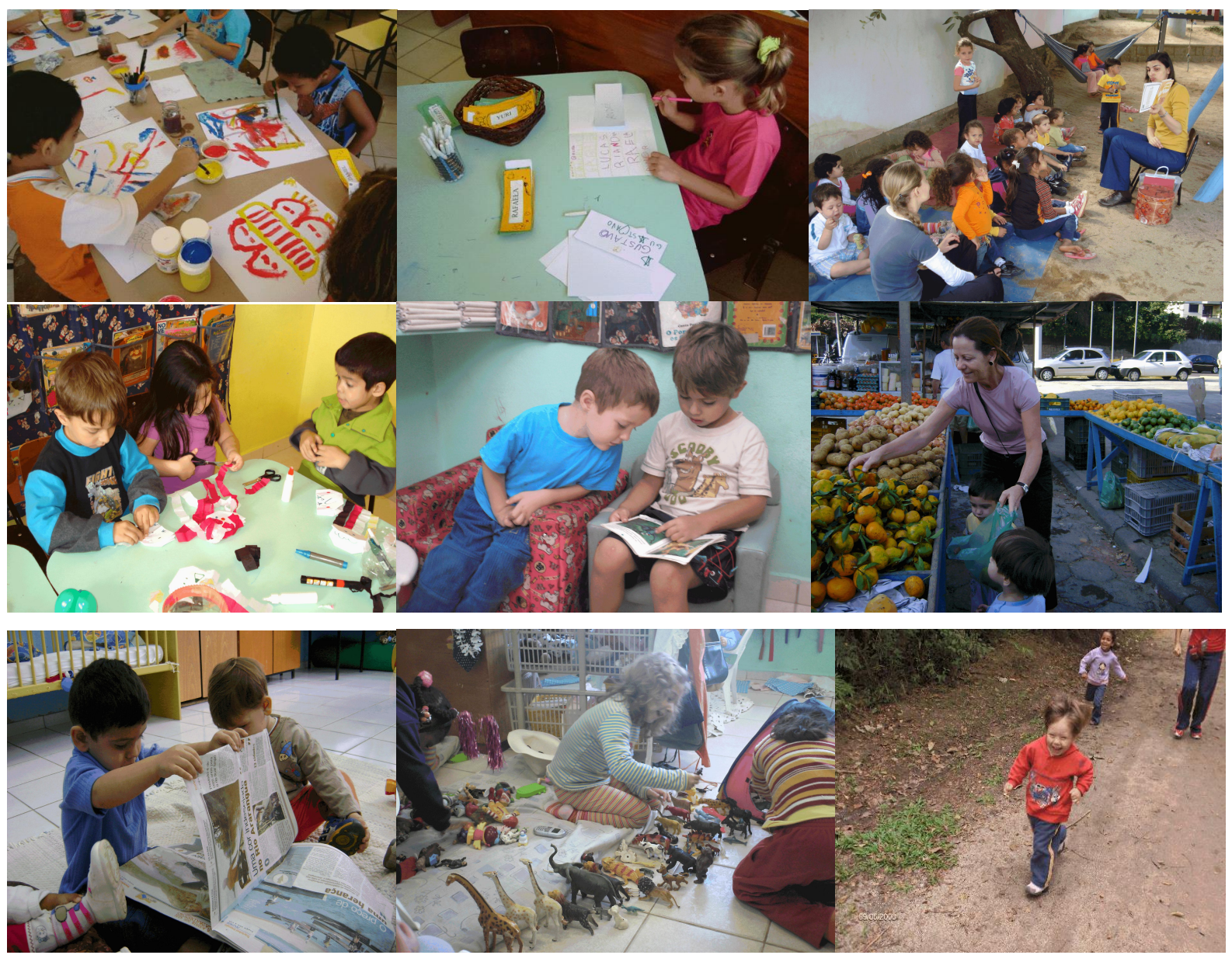
Com o mesmo propósito de diversificação das vivências, temos dado especial atenção ao trabalho realizado em pequenos grupos. Através de uma parceria entre os dois educadores que trabalham nas salas de referência: professor e auxiliar de sala, temos conseguido assegurar o trabalho em agrupamentos menores. Esta ação passou a se efetivar em todos os grupos após o estágio de 2006, quando, no Projeto de Estágio articulado com o curso de Pedagogia da UFSC, as alunas da universidade observaram uma prática que já acontecia na creche nos grupos de crianças maiores e registraram que "[...] os trabalhos em pequenos grupos abrem-se como possibilidade para a escolha da criança, por interesse de tema/brincadeira/espaço, tornando estes momentos ainda mais significativos". Assim, "[...] através da observação e da escuta atenta e cuidadosa às crianças, podemos encontrar uma forma de realmente enxergá-las e conhecê-las. Ao fazê-lo, tornamo-nos capazes de respeitá-las pelo que elas são e pelo que elas querem dizer". (GANDINI et al, 2002, p. 152).
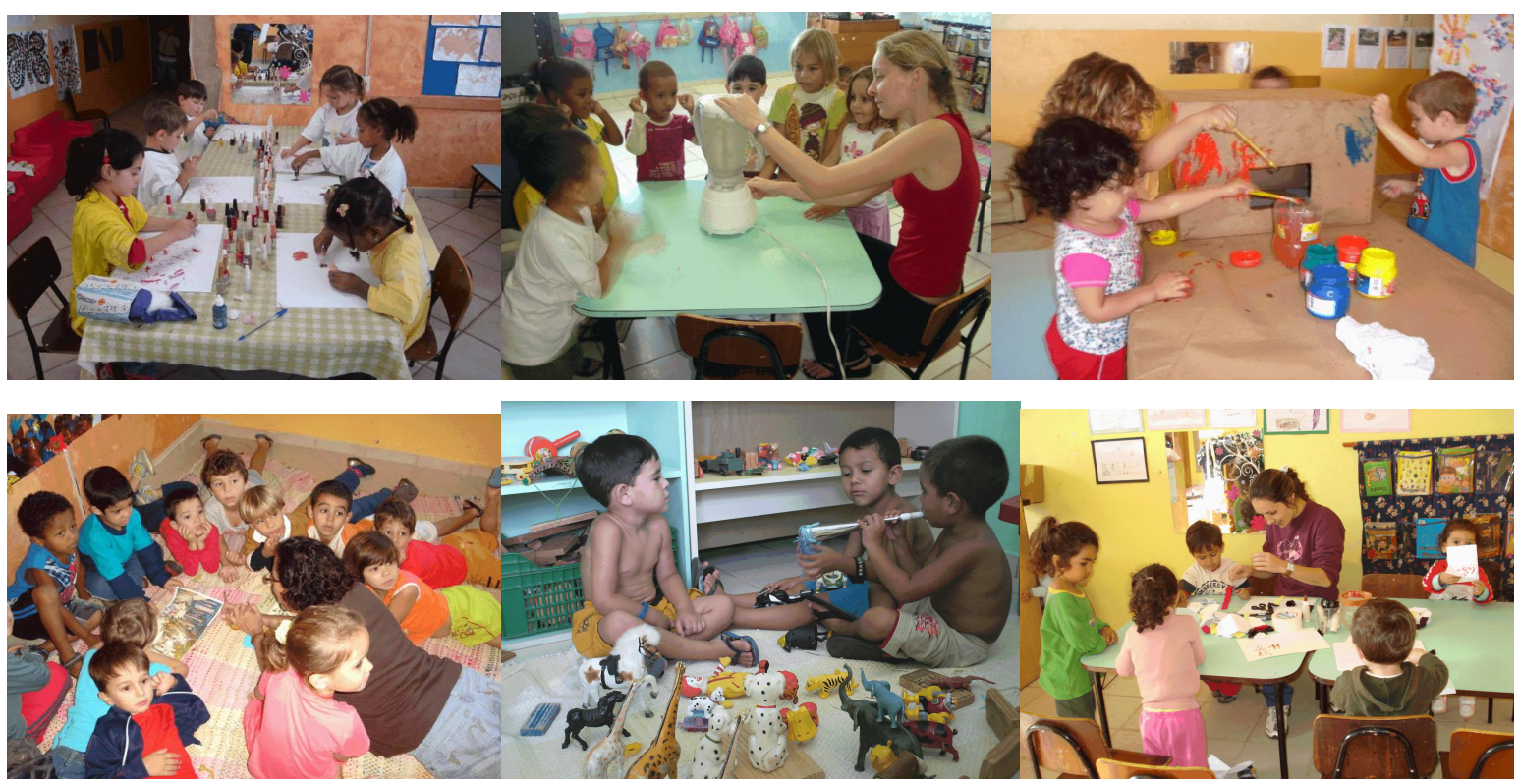

Pensando na ampliação e diversificação, temos algumas músicas/cantigas que fazem parte do nosso cotidiano. Com a preocupação em garantir um repertório "mínimo" a creche tem um rol de músicas, que selecionamos com o intuito de que todas as crianças de todos os grupos tenham acesso ao mesmo. Para além dessas, constantes do acervo selecionado, os educadores costumam acrescentar outras, relacionadas aos seus repertórios e/ou temas de seus projetos. Para garantir a ludicidade do momento da roda de música, criamos e utilizamos as "caixinhas de música", o microfone e a caixa amplificadora, às vezes acompanhados com violão. Estratégias como estas permitem que as crianças participem com entusiasmo da cantoria. 


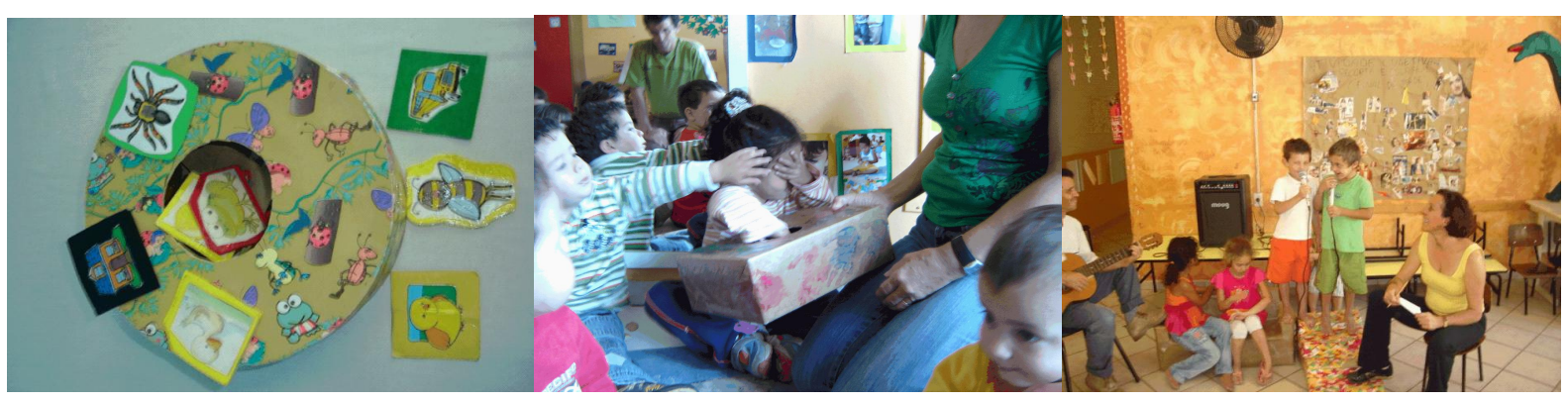

\section{A acolhida das crianças e familiares: da inserção à continuidade}

No início do texto tratamos de informar como acontece a acolhida dos educadores na creche. Agora julgamos ser interessante apresentar como temos pensado a acolhida das crianças e seus familiares.

Início de ano: tempo de conhecer para alguns, mas tempo de reencontrar para a maioria. Este período de inserção é, então, cuidadosamente planejado. Não negamos: temos, ano após ano, repetido muitas ações que segundo nossas avaliações têm minimizado a angústia e insegurança, neste período de grande importância na vida das crianças e adultos. Procuramos ser respeitosos com as crianças e também com suas famílias, preparando espaços para acolher crianças e adultos.

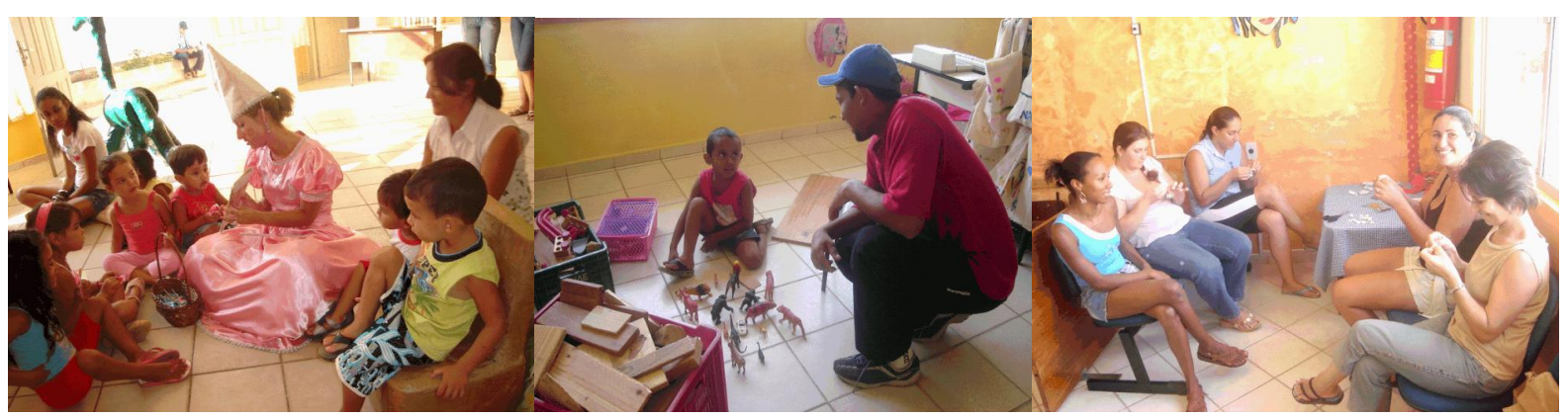

Algumas ações que ocorrem no período de inserção, com o objetivo de reforçar a relação entre a creche e a família, continuam a acontecer durante todo o ano. Todos os dias pela manhã, e no final de tarde, acontece o Projeto Acolhida e Despedida que tem por objetivo maior "Favorecer o Encontro". Este espaço é organizado pelos auxiliares de sala e permite a interação entre as crianças de diferentes grupos. Neste momento, alguns pais aproveitam o espaço e brincam com os filhos... Há também possibilidade para brincadeiras entre irmãos, inclusive, enquanto o horário da Escola ao lado não chega, ou mesmo, quando já terminou.

As crianças ocupam vários espaços, podendo brincar também com diferentes materiais. 
Durante os seis anos de execução desse projeto temos observado uma tendência que é bastante recorrente: quando chegam as crianças normalmente tendem a ficar próximas ou brincando com amigos do mesmo grupo, ou até de outros grupos; já no final da tarde, talvez em função da saudade, é perceptível o fato delas optarem por ficar brincando junto com irmãos e/ou vizinhos.
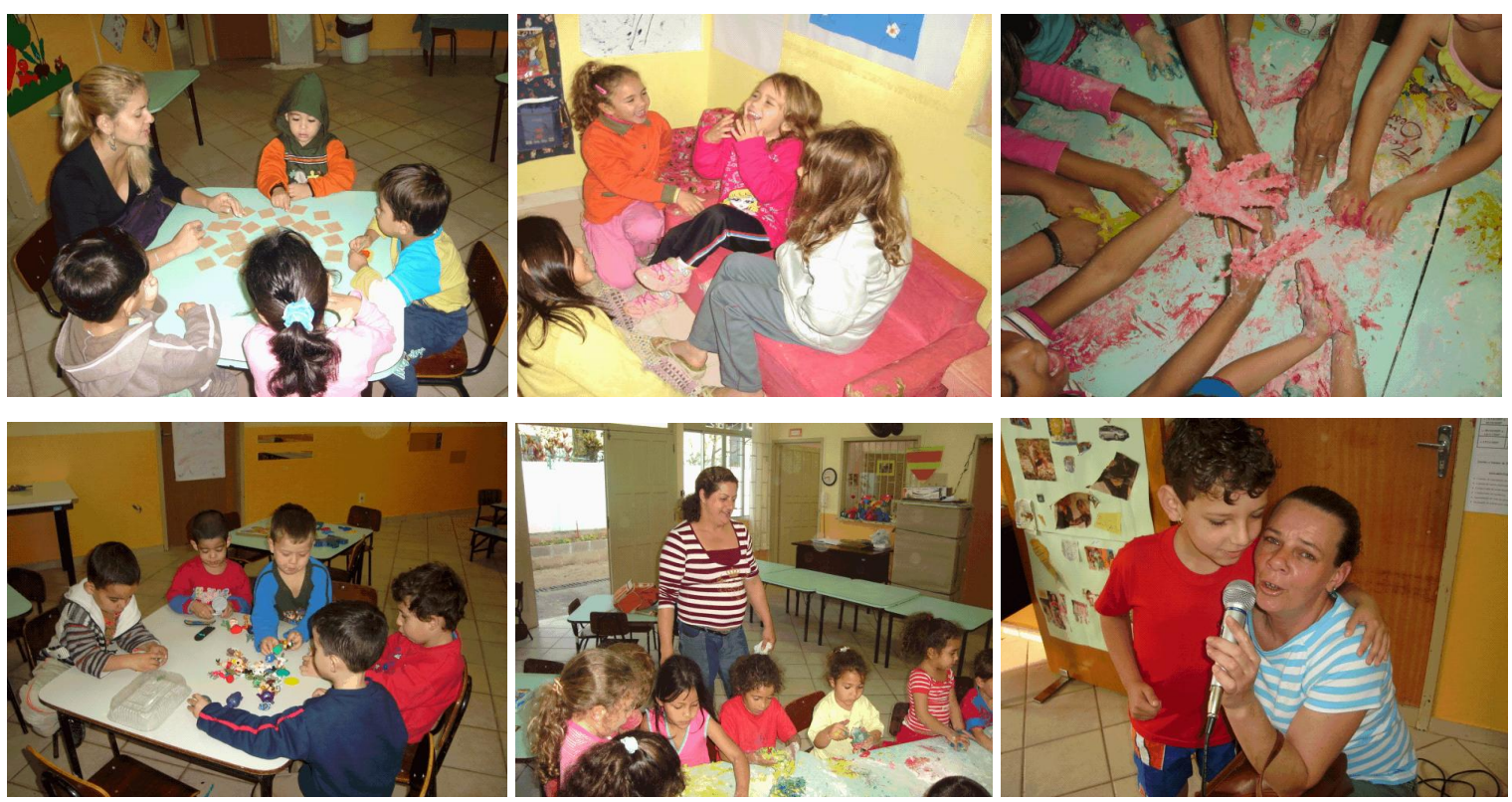

Procurando firmar essa aproximação, temos também a ficha de acompanhamento diário, como um outro recurso de relação creche-família. Esta ficha é utilizada nos grupos 1 e 2, e é uma forma de manter os pais informados sobre o cotidiano das crianças na creche. Diante da sensibilidade da vida nestes primeiros anos, entendemos que é importante registrar para observar e conhecer questões referentes à alimentação e às necessidades fisiológicas. Como forma de informar aos pais, registramos também as atividades mais relevantes realizadas no dia junto às crianças daquele grupo, assim como os espaços explorados por elas nesse dia.

Através da leitura dessas fichas os pais sabem sobre os alimentos servidos naquele dia, se a criança comeu ou não, se defecou, dormiu, do que brincou, em que espaços esteve. Analisando os registros dessas fichas, ao longo das semanas, vamos conhecendo um pouco mais as nossas crianças e permitindo que os pais, uma vez que a maioria das crianças ainda não utiliza a linguagem oral, acompanhem também o dia-a-dia delas na instituição. 
Ficha de Acompanhamento das Atividades Desenvolvidas Junto às Crianças do Grupo I

DIA

DATA

1

Atividades/espaços e brincadeiras da manhã.

Atividades/espaços e brincadeiras da tarde.

Atividades Permanentes:

Criança - Lanche manhã - Almoço - Lanche tarde - Janta - Troca de cocô Sono

As reuniões com as famílias também têm se constituído em importantes momentos de aproximação. Nas reuniões bimestrais por grupo, trocamos informações sobre o trabalho realizado no período e falamos sobre projetos para o próximo período. Os Pais precisam saber sobre o que se faz, não podem ficar só no simbólico, muitos não viveram a experiência de ter ido à creche e os que tiveram, vivenciaram uma outra fase da educação infantil. Temos priorizado a apresentação, do que foi realizado, por meio de fotografias ou filmagens o que tem possibilitado a visualização e a compreensão de todos e, de certa forma, dado uma credibilidade ao trabalho. Falo em credibilidade porque hoje, alguns pais relatam que, muitas vezes, quando falávamos que as crianças faziam determinadas atividades, como por exemplo, se servirem sozinhas nos momentos da alimentação, diziam não acreditar, ou não conseguiam imaginar, como seus filhos, tão pequeninos e dependentes em casa, poderiam realmente estar fazendo o que a professora contava. Assim, essa forma de documentação também tem nos ajudado a dar visibilidade ao que acontece dentro da creche.

Outra estratégia utilizada é procurar trazer ao máximo trazer as falas das crianças, para apresentar os trabalhos. Dizemos que podemos apresentar as vivências, utilizando a voz das crianças. Mas essa ação requer um bom registro no cotidiano. É importante escrever o que elas dizem, já sabem, aprenderam, gostam e sentem.

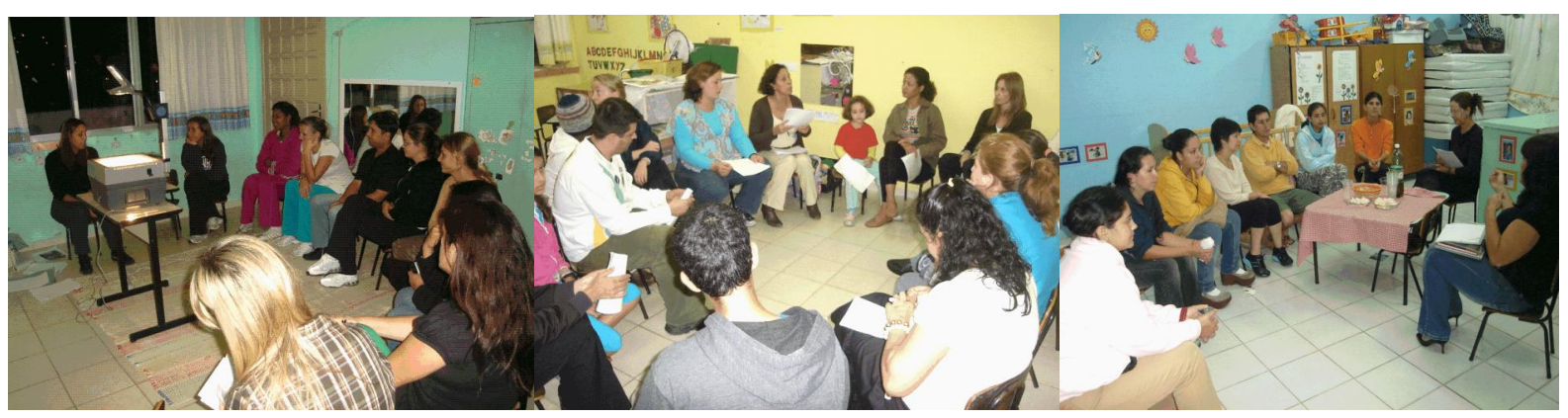


Como elementos importantes de relação com as famílias temos ainda os "mascotes", "caixa surpresa" ou livros que as crianças podem levar para casa. Estes elementos são também importantes elos entre a vida das crianças na creche e a vida que elas têm em casa, com suas famílias. Juntamente com o mascote vai um diário. Isso requer uma atenção da família para o registro, por escrito ou desenhado, daquilo que aconteceu em casa com o "amigo" que foi visitá-lo. A leitura/apresentação para o grupo da aventura do mascote, vivenciada em casa, é sempre um momento muito esperado pelo grupo. Alguns pais incluem fotos e recortes, que dão ainda mais detalhes e emoção às histórias.
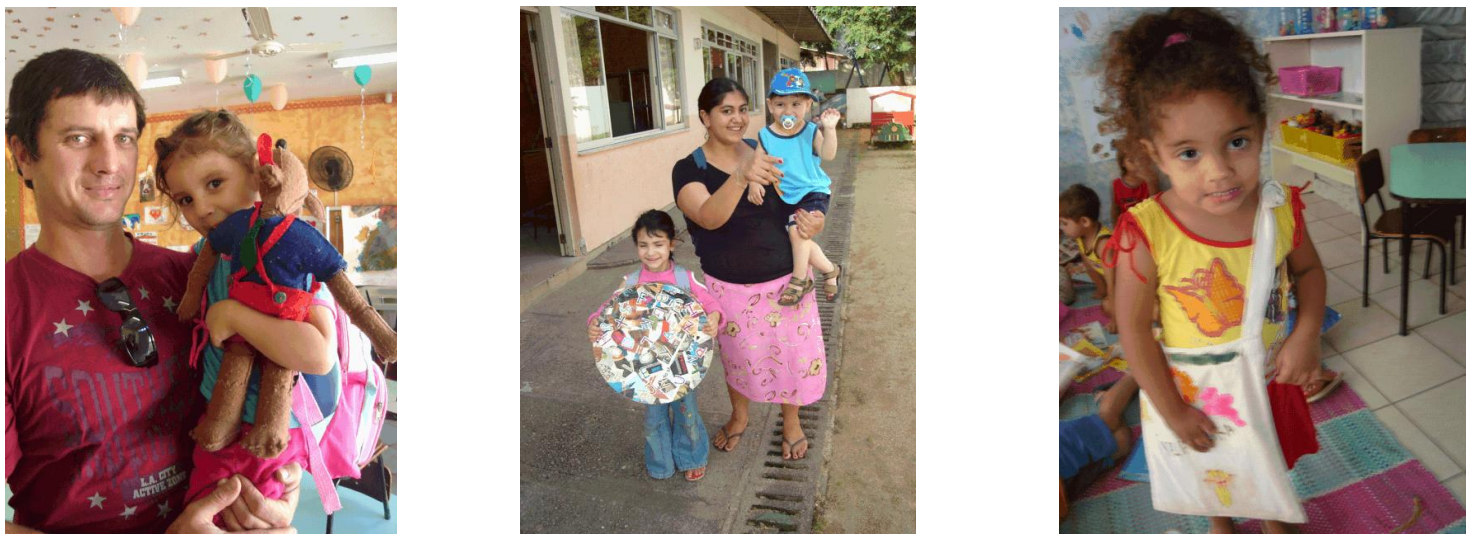

Todas estas ações pretendem construir relações, especialmente, relações de confiança. Enquanto divulgamos o nosso trabalho, os pais vão conhecendo e apropriando-se da forma como temos encaminhado a organização dos tempos, espaços e materiais para os seus filhos. O porquê disso e não daquilo, as escolhas que fazemos, precisam ser comunicados aos pais para que haja compreensão, pois embora muitas vezes nos esqueçamos, a grande maioria dos pais não é da nossa área e por isso não tem a obrigação de saber do nosso trabalho.

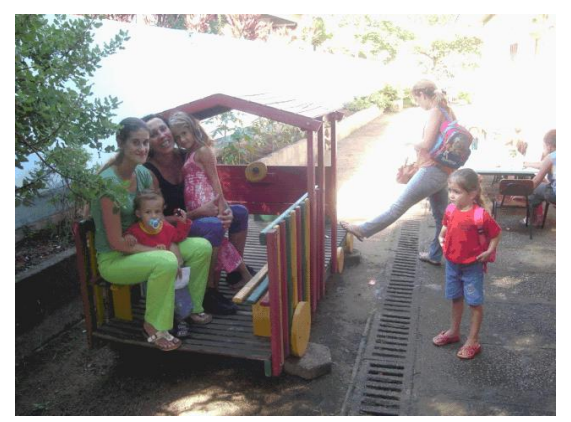

\section{Educadores e pais precisam "viajar" juntos...}

Acreditamos que o alimento integra... Assim, nas confraternizações que realizamos, sempre oferecemos algum tipo de alimentação. Procuramos criar meios das crianças participarem da preparação dos alimentos que serão servidos. Algumas vezes, por exemplo, os legumes da sopa são cortados pelas crianças no projeto culinário. Pensando em potencializar as relações entre pais e filhos 
organizamos momentos e planejamos espaços que potencializam as relações entre pais e filhos, pois acreditamos que em pequenos gestos podemos transmitir valores, atenção, carinho...

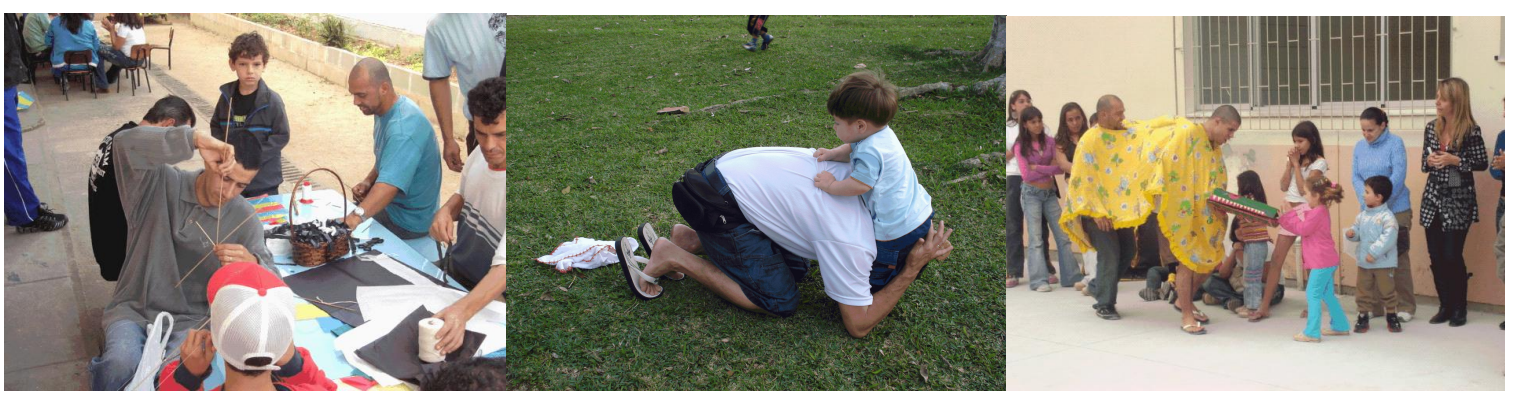

Conhecer o mundo é fascinante, junto com os pais, é maravilhoso...
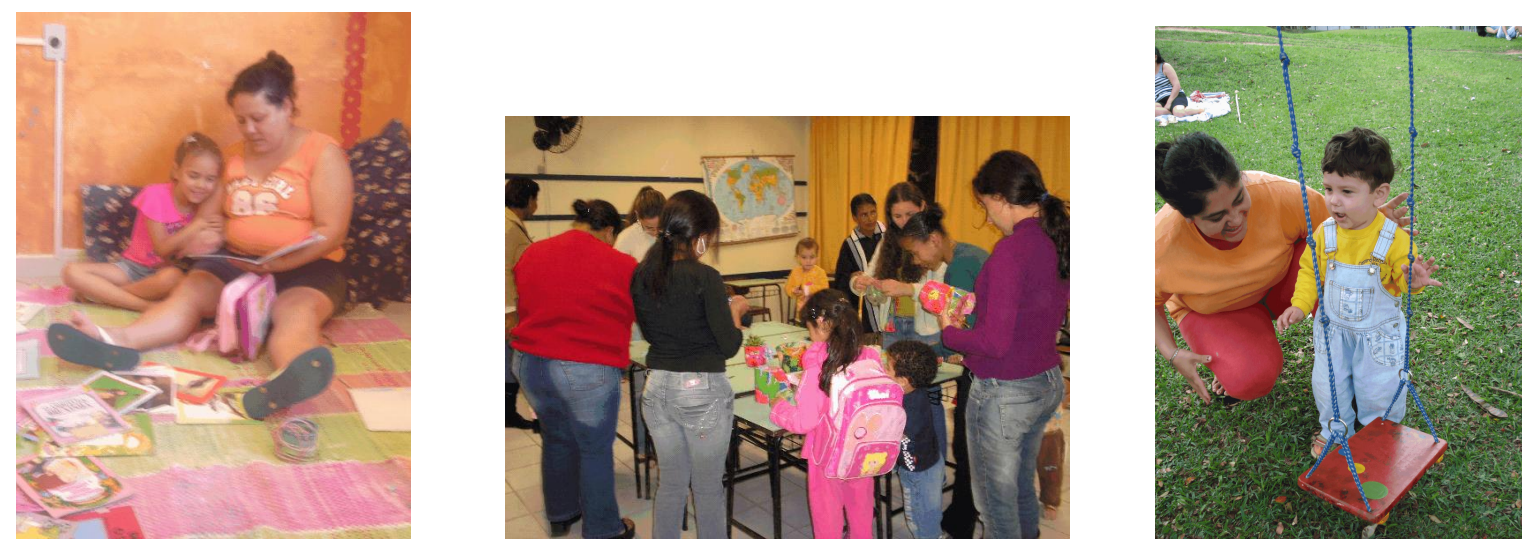

\section{A contribuição da Educação Física}

Conforme o já explicitado, nossa Instituição conta com o trabalho de uma professora de Educação Física. O trabalho desta profissional na educação infantil é bastante recente e aqui em Florianópolis há um grupo bastante comprometido em construir uma proposta diferenciada, procurando demarcar a sua ação nesta área na infância. Nossa experiência é bastante positiva, uma vez que a profissional dessa área tem procurado desenvolver um trabalho sem horários fragmentados e em parceria com os profissionais de sala, procurando envolver nos seus projetos crianças de diferentes grupos. Não é um trabalho separado, corpo-mente, razão-emoção, movimento-cognição, sendo que sua especificidade e especialidade alimentam o trabalho e ajudam a pensar nossas práticas.

Hoje, existem três trabalhos que são coordenados pela profissional da Educação Física. Um deles já existia, mas não tinha uma periodicidade e a organização que tem no momento, pois teve um salto, tanto qualitativo como quantitativo, quando essa profissional o tomou como parte de sua responsabilidade a organização e seqüência deste projeto.

Embora já tenha indicado algumas características desse projeto, dos outros dois desenvolvidos e organizados por essa profissional, falarei a seguir sobre cada um deles. 
Organização dos espaços para atividades coletivas: Concordamos com as afirmações de FERREIRA, 2004, p.65:

"As condições de um rico" ambiente interacional referem-se, especialmente à existência de parceiros envolvidos afetivamente com a criança e disponíveis para interagir com ela, o que inclui os adultos e as outras crianças da creche, e também a presença de suportes ambientais que favoreçam a interação".
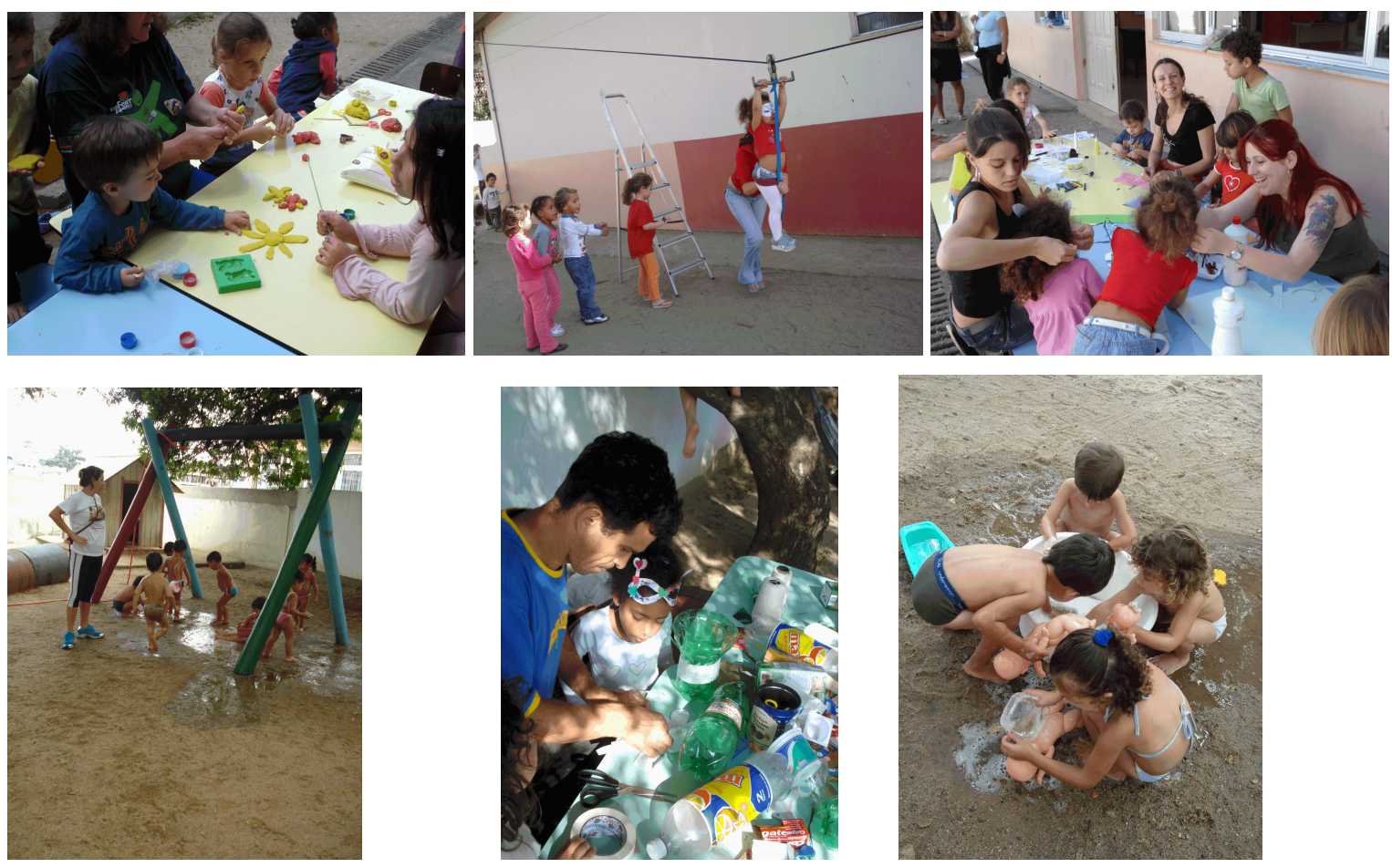

Partindo dessa premissa temos, então, espaços planejados para potencializar a brincadeira, a criação, a fantasia, a imaginação, espaços esses que buscam oportunizar tanto brincadeiras individuais como coletivas. Nesses espaços de interação e aprendizagens é permitida a vivência de outras experiências, movimentos amplos, expressões e linguagens.

O Parque nas segundas-feiras: Neste caso, o espaço é alterado, colocam-se ali elementos que configuram novas possibilidades de ocupá-lo. A cada segunda-feira uma surpresa, em cada semana um elemento novo a explorar.
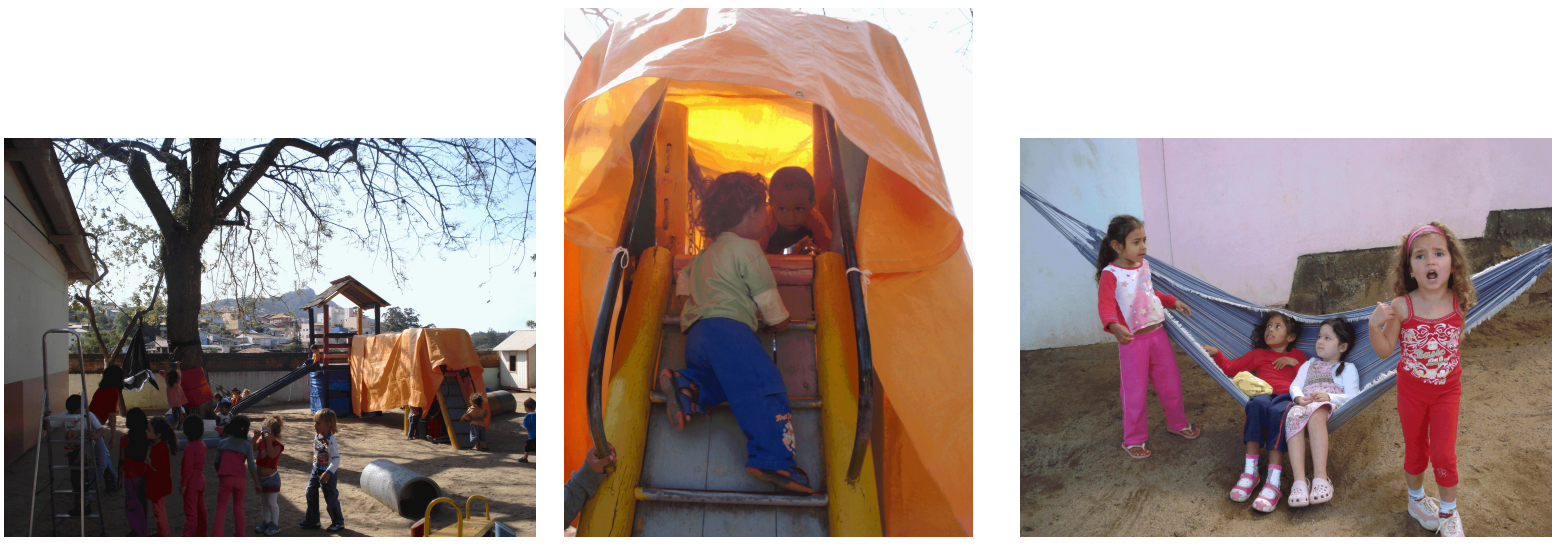
Saídas e Passeios: Poder estar mais próximo da natureza, em espaços onde é possível conhecer novas geografias, novos territórios, explorar diferentes movimentos em espaços antes nunca explorados. Tem se constituído em mais um dos direitos que procuramos assegurar às nossas crianças, nessa proposta de trabalho. Para garantir esse direito, no nosso caso, pressupõe sair da instituição, já que nosso parque é pequeno e requer inclusive um horário de ocupação. Assim, existe uma certeza, é preciso ir "além dos muros" da creche, inclusive com os bebês.

Acreditamos que as crianças têm que ter direito de ter outros ângulos, ver outras coisas que existem no mundo. Dessa forma, podem fazer muitas perguntas, elaborar conceitos e a partir dessas saídas contar também muitas aventuras.
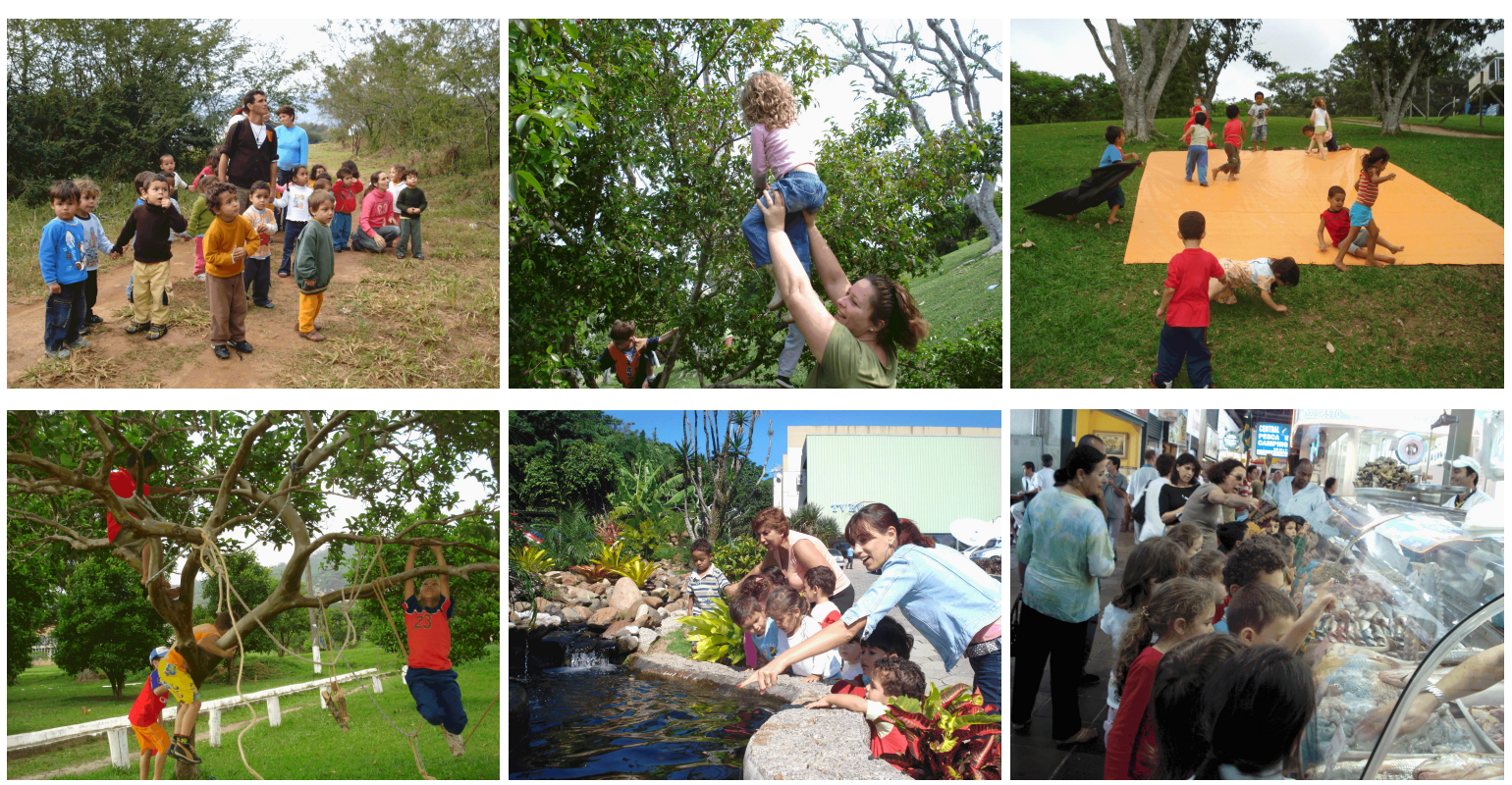

O Boi-de-Mamão: O boi-de-mamão, como marca cultural da comunidade, entrou na instituição há muito tempo, com o objetivo claro de manter viva a cultura desta dança, dentro e fora da creche, procuramos envolver no enredo as crianças, desde o berçário, bem como os adultos educadores e os familiares. A partir de 2001 a profissional da Educação Física tomou nas mãos esta brincadeira, colocando a cultura como um dos focos da proposta pedagógica. O boi-de-mamão, ou simplesmente o boi, como é conhecido na creche, vem tomando mais força a cada ano. Crianças e adultos, cada vez mais, brincam e se encantam com os sentidos e significados revelados nos personagens e cantigas do boi.

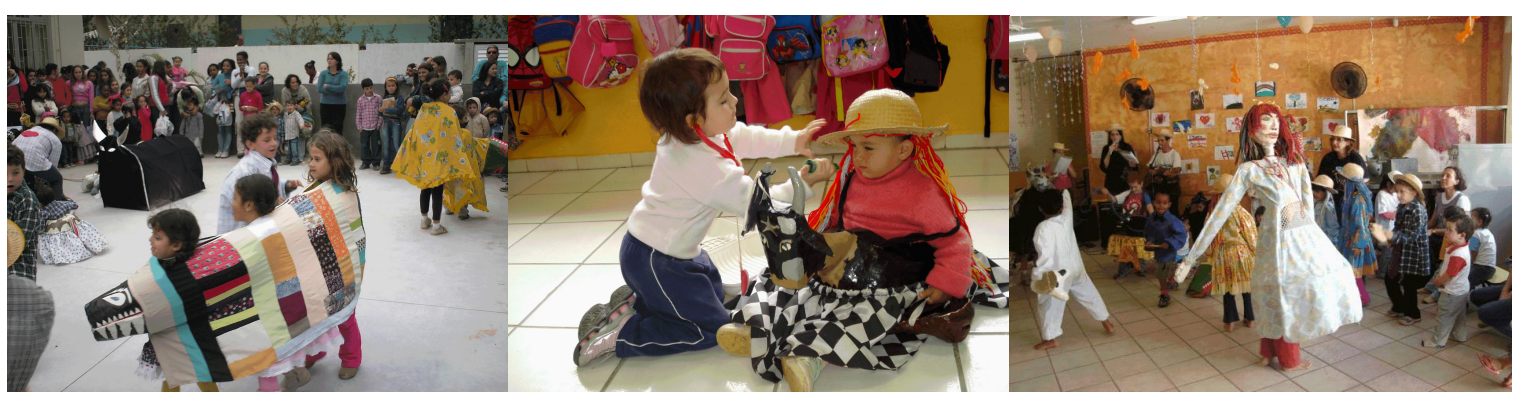




\section{Formação em serviço}

Refletindo sobre a necessidade e possibilidade de um trabalho em parcerias, e de como conseguir articular todo esse trabalho com um grupo que não é permanente, que se altera a cada ano, em função de substituições e afastamentos, elegemos como central a formação em serviço. Para além, de todas as organizações e concepções asseguradas no nosso PPP, destacamos o espaço destinado à formação em serviço. Temos, em nossa instituição, ao longo desses anos, procurado direcionar a formação em serviço por caminhos que levem a refletir sobre as práticas, ampliar o conhecimento teórico e as vivências de repertórios estéticos, artísticos e culturais.

Felizmente contamos, em muitas oportunidades, com parceiros que nos apoiam e orientam nossas ações. Podemos citar, entre outros, as Universidades UFSC e UDESC com os estágios e projetos de extensão, os consultores durante as formações descentralizadas, as orientações para os grupos de estudo e os patrocínios para alguns projetos de saídas e passeios.

Como já mencionado, compreendemos que para a construção desse trabalho educativo é importante a participação de todos os segmentos da instituição. Todo espaço educativo, por ser um espaço de relações humanas, é sempre educativo, seja intencional ou não, educa! Por isso, acreditamos que todas as relações estabelecidas na Creche são educativas. Dessa forma, defendemos a participação de todos na formação em serviço. Como educadores devemos acreditar e apostar que todos podem aprender.

Esta formação poderia ser didaticamente dividida em dois grandes núcleos. A Formação geral, que se constitui de momentos onde todos os educadores participam, como os grupos de estudo, as reuniões pedagógicas e o projeto de educação estética. E a Formação específica, como o próprio nome diz, é restrita a alguns segmentos, sendo que esta formação acontece nos encontros para assessoramento do planejamento, com professores e auxiliares de sala e durante os estágios do curso de pedagogia.

Citando especificamente a formação junto aos estágios poderíamos dizer que cada uma das propostas de estágio, a partir de 2003, contribuiu significativamente para a qualificação dos nossos trabalhos, uma vez que abriu novas possibilidades quanto a aspectos como: privilegiar o exercício do olhar e do registro, focar e analisar de forma ampliada os movimentos das crianças e seu dia-a-dia na creche, através das observações das falas, das ações e interações crianças-criança, criança-adulto, adulto-criança. Com o estágio também pudemos aprofundar o conhecimento sobre as brincadeiras das crianças e suas interações, ampliando os momentos de encontro e troca entre elas na creche. Tivemos a oportunidade de ampliar a reflexão sobre a importância do planejamento e organização dos espaços, para criar novas possibilidades, diferentes materiais e favorecer, assim, o contato com outras linguagens.

Os Grupos de estudo são encontros que acontecem todas as segundas-feiras, na sala, conhecida na creche, como sala do vídeo. Com uma hora de duração, e com a participação de todos os 
funcionários da instituição. Nesses grupos de estudo realizamos reflexões a partir de textos selecionados e escolhidos, para aprofundar os temas definidos para o semestre.

Para além das reflexões teóricas temos também outras escolhas, temos investido na pessoa do educador. Pois assim como aponta Jennifer Nias, (apud NÓVOA, 2000, p.9), “[...] o professor é a pessoa; e uma parte importante da pessoa é o professor".

Acreditamos que a formação deva contribuir, para que os educadores desenvolvam-se em todas as dimensões do humano. Afinal, arte e ciência, uma e outra, são marcas do humano (OSTETTO, 2007).

A necessidade de uma formação para educadores, que contemple também experiências estéticas está posta, e por isso, para além do instituído temos procurado realizar ações para incentivar e garantir o acesso dos educadores aos espaços de lazer e cultura na cidade e também fora dela. Investimos numa educação para o sensível, que pretende desacomodar o hábito. É preciso alimentar a imaginação: "Recuperar o ser poético que é a criança só é possível quando os professores se percebem como pessoas capazes de viver o estranhamento, que é o ser da poesia, quando o professor descobre nele mesmo o prazer da criação" (ALBANO, 1999, p. 127.)

Também na formação em serviço temos um projeto que é definido como: "Vamos ver o que tem lá fora”, que se efetiva na organização de saídas para lugares nos quais os educadores podem vivenciar uma aproximação, com a arte ou com diferentes paisagens, junto à natureza.

Em viagens, já temos alguns "carimbos em nosso passaporte". No ano de 2002 fomos a uma noite competitiva no Festival de Dança de Joinville e passamos um dia na Estância Hidromineral de Caldas da Imperatriz. Em 2003, retornamos na noite de estréia ao Festival de Dança de Joinville e no final do ano fomos até a praia de Itapirubá. No ano seguinte, fomos mais longe: visitamos a cidade de São Paulo, visitamos a Bienal, fomos até a Creche da OAB e ao Masp. Em 2005 estivemos no simpático município de São Martinho, Gravatal e ainda na Praia da Solidão. Em 2006 retornamos à Bienal, aproveitamos para conhecer a Pinacoteca, o Museu da Língua Portuguesa e o Museu da FAAP. Já em 2007, estivemos no Centro de transbordo e o Museu do Lixo, aqui mesmo de Florianópolis, visitamos a Exposição Internacional Camille Claudel, no Masc, e, três educadoras participaram do VI Encontro Brasileiro de danças Circulares Sagradas - Embu das Artes/SP. Para este ano de 2008, pretendemos retornar a Cidade de São Paulo, visitar a $28^{\mathrm{a}}$ Bienal Internacional de Arte/SP e a conhecer a Escola Te-arte. Pela experiência adquirida podemos dizer que o conjunto de todas essas ações tem nos tornado, ano após ano, mais atentos, reflexivos, cuidadosos, sensíveis ao trabalho, aos outros e a nós mesmos.

Enriquecem-se os acervos pessoais, alimentando a imaginação, e leva-se o educador a reconciliar-se com a própria expressão, resgatando a palavra, o traço, as idéias e a autoria (DIAS, 1999). Um dos desafios para a formação dos educadores hoje, certamente passa pela formação de um ser inteiro, o mesmo que desejamos para nossas crianças! 

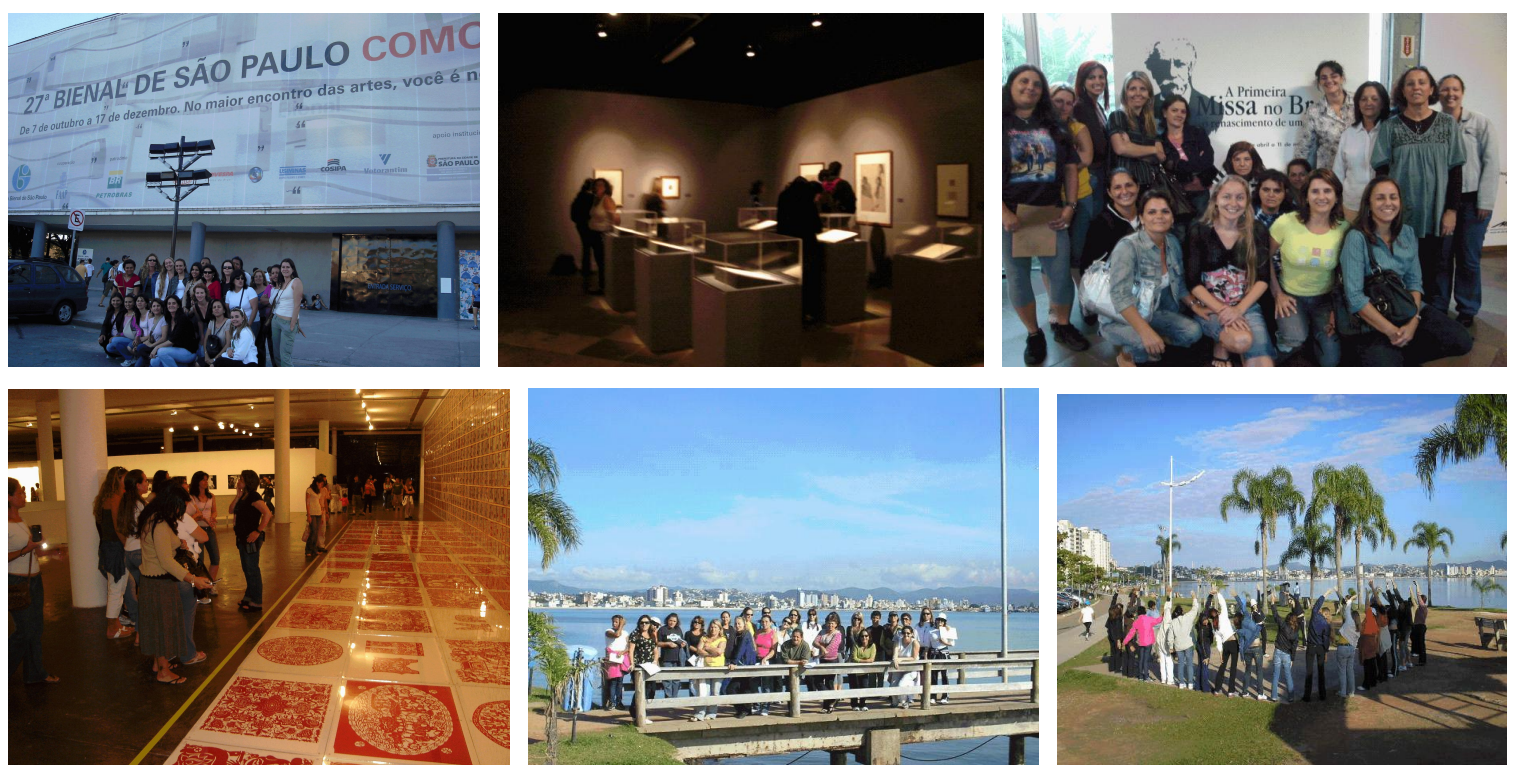

Nossa concepção de educação vai norteando nossa intervenção da prática. Assim como proferiu recentemente na UFSC a doutoranda Márcia Buss. "Não precisamos "trocar" as nossas práticas por "novas" práticas, precisamos sim nos conscientizar de nossas práticas, refletindo sobre elas, dialogando com as teorias."

\section{Referências Bibliográficas}

ALBANO, Ana Angélica. O espaço do desenho: a educação do educador. São Paulo: Edições Loyola, 1999.

DIAS, Karina Sperle. Formação Estética: em busca do olhar sensível. IN: Infância e Educação Infantil. (vários organizadores)Campinas, SP: Papirus, 1999. Coleção Prática Pedagógica.

FARIA, Ana L. G. O espaço físico como um dos elementos fundamentais para uma pedagogia da educação infantil. In: Faria, Ana L. G. e PALHARES, Marina S. (org) Educação Infantil pós-LDB: rumos e desafios. Campinas, SP: Autores Associados - FE/UNICAMP; São Carlos, SP: Editora da UFSCcar; Florianópolis, SC: Editora da EFSC, 1999.

FERREIRA, Manoela. Do Avesso do Brincar ou... as relações entre pares, as rotinas da Cultura e a Construção da(s) Ordem(ens) Social (ais) Instituinte (s) das Crianças no Jardim-de-infância. In Samento \& Cerisara, Ana Beatriz. Crianças e Miúdos: perspectivas sociológicas da infância e educação. Portugal: Asa Editora, 2004 (p. 55-104).

GANDINI, Lella. Espaços Educacionais e de Envolvimento Pessoal. In: EDWARD, GANDINI \& FORMAM. As cem linguagens da criança: abordagem de Reggio Emilia na educação da primeira infância. Porto Alegre, Editora Artes Médicas, 1999.

GANDINI, Lella \& EDWARDS, Carolyn. Bambini: uma abordagem italiana à educação infantil. Porto Alegre: Artmed, 2002 
KATZ, Lilian. O que podemos aprender com Reggio Emilia? In: EDWARDS, Carolyn, GANDINI, Lella, FORMAN, George. As cem linguagens da criança: abordagem de Reggio Emilia na educação da primeira infância. Porto Alegre: ArtMed, 1999

NÓVOA, A (Org). Os professores e a profissão. Lisboa: Don Quixote, 1992.

OSTETTO, Luciana Esmeralda. Entre a prosa e a poesia: fazeres, saberes e conhecimento na educação infantil. In: PILLOTTO, Silvia (Org.). Linguagens da arte na infância. Joinville: Univille, 2007 (p.30-45).

Zabalza, Miguel A. Qualidade em Educação Infantil: A organização dos Espaços na Educação Infantil, FORNEIRO, Lina Iglesias. Cap. 11, Porto Alegre: ArtMed, 1998. 